\title{
Neural Circuitry and Neuroplasticity in Mood Disorders: Insights for Novel Therapeutic Targets
}

\author{
Paul J. Carlson, ${ }^{* \dagger}$ Jaskaran B. Singh, ${ }^{*}$ Carlos A. Zarate Jr., ${ }^{*}$ \\ Wayne C. Drevets, ${ }^{\dagger}$ and Husseini K. Manji* \\ *Laboratory of Molecular Pathophysiology, ${ }^{\dagger}$ Section on Neuroimaging in Mood Disorders, Mood and Anxiety Disorders \\ Research Program, National Institute of Mental Health, Bethesda, Maryland 20892
}

\begin{abstract}
Summary: Major depressive disorder and bipolar disorder are severe mood disorders that affect the lives and functioning of millions each year. The majority of previous neurobiological research and standard pharmacotherapy regimens have approached these illnesses as purely neurochemical disorders, with particular focus on the monoaminergic neurotransmitter systems. Not altogether surprisingly, these treatments are inadequate for many individuals afflicted with these devastating illnesses. Recent advances in functional brain imaging have identified critical neural circuits involving the amygdala and other limbic structures, prefrontal cortical regions, thalamus, and basal ganglia that modulate emotional behavior and are disturbed in primary and secondary mood disorders. Growing evidence suggests that mechanisms of neural plasticity and cellular resilience, in-
\end{abstract}

cluding impairments of neurotrophic signaling cascades as well as altered glutamatergic and glucocorticoid signaling, underlie the dysregulation in these circuits. The increasing ability to monitor and modulate activity in these circuits is beginning to yield greater insight into the neurobiological basis of mood disorders. Modulation of dysregulated activity in these affective circuits via pharmacological agents that enhance neuronal resilience and plasticity, and possibly via emerging nonpharmacologic, circuitry-based modalities (for example, deep brain stimulation, magnetic stimulation, or vagus nerve stimulation) offers promising targets for novel experimental therapeutics in the treatment of mood disorders. Key Words: Affective circuitry, bipolar disorder, brain imaging, major depressive disorder, functional imaging, therapeutics, plasticity.

\section{INTRODUCTION}

Major depressive disorder (MDD) and bipolar disorder (BD), two of the most severely debilitating medical illnesses, ${ }^{1}$ affect the lives and functioning of millions worldwide. MDD and BD have historically been conceptualized as episodic illnesses with full recovery between episodes. However, a growing number of studies indicate that, for a significant number of patients, outcome is quite poor, with high rates of relapse, chronicity, lingering residual symptoms, subsyndromes, cognitive and functional impairment, psychosocial disability, and diminished well-being. ${ }^{2-5}$ Suicide is estimated to be the cause of death in up to $15 \%$ of individuals with mood disorders. In addition to this serious health risk, systemic manifestations of other medical conditions commonly co-occur in patients with a mood disorder. ${ }^{6-9}$

Address correspondence and reprint requests to Husseini K. Manji, M.D., 35 Convent Drive, MSC 3711, Building 35, Room 1C-917. Bethesda, MD 20892.
Despite the clinical impact of these disorders on patient's lives, their families and the community, the current understanding of the precise neurobiological underpinnings of MDD and BD is limited. Historically, the focus in neurobiologic studies of mood disorders has been the monoaminergic neurotransmitter systems, which are extensively distributed throughout the network of limbic, striatal, and prefrontal cortical neuronal circuits thought to support the behavioral and visceral manifestations of mood disorders. ${ }^{10,11}$ Whereas these neurotransmitter systems undoubtedly play an important role in modulating the expression of certain signs/symptoms of mood disorders, the currently approved treatments that primarily target these systems have a number of drawbacks including delayed clinical response/remission (weeks to months) and, too frequently, incomplete or absent response/remission.

Clearly, there is a great clinical need for the ongoing development of new therapies that are more effective, rapid-acting, and easily tolerated than existing therapies. 


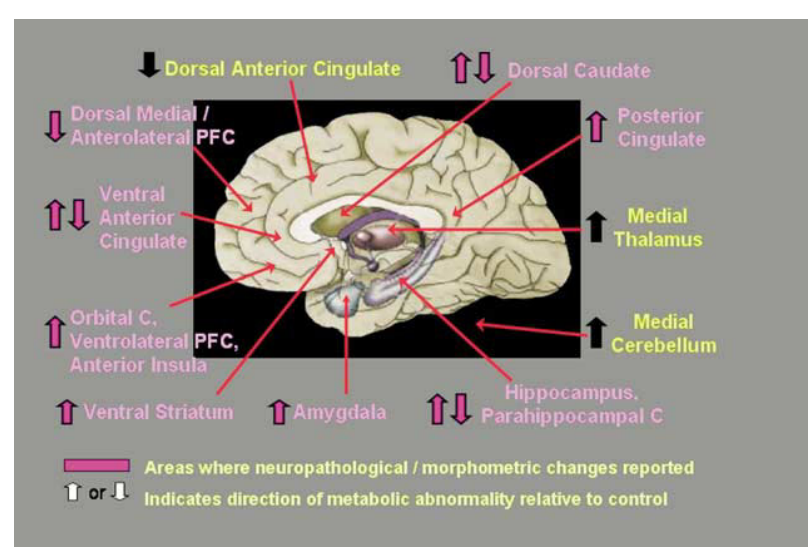

FIG. 1. Abnormalities in metabolism and structure in mood disorders. $\mathrm{C}=$ cortex; PFC $=$ prefrontal cortex. Modified from Drevets 2005.

In this review, we discuss the prospect of developing new treatments for mood disorders based upon two approaches:

1) Understanding the nature of critical neural circuits that are dysregulated in individuals with mood disorders, and using this knowledge to develop strategies to directly manipulate activity in these circuits.

2) Understanding the disturbances of neural plasticity and cellular resilience that seem to underlie aberrant activity in these circuits, and targeting therapeutics to attenuate or prevent these pathological processes.

\section{1) NEURAL CIRCUITRY IN MOOD DISORDERS: IMPLICATIONS FOR EXPERIMENTAL THERAPEUTICS}

A greater understanding of the neural circuits underlying mood in both normal and abnormal affective states has been identified as one of the critical needs in the field of mood disorders research. ${ }^{11}$ The early yet significant advances made in this area in recent years are beginning to provide a neuroanatomical framework in which to better understand mechanisms of current treatment modalities and guide efforts for the development of novel therapeutics. The following sections summarize a variety of neuroanatomic findings that hold potential therapeutic implications for mood disorders.

\section{Functional anatomy of mood disorders}

Functional imaging studies of mood disorders have identified key brain regions involved in a network of limbic, striatal, and prefrontal cortical circuits thought to support the behavioral, cognitive, and visceral manifestations of mood disorders. ${ }^{10-13}$ Key brain regions that have shown consistent abnormalities in mood disorders are discussed below (see FIG. 1).

The amygdala. Resting cerebral blood flow (CBF) and glucose (GLC) metabolism in the amygdala have consistently been demonstrated to be elevated in individ- uals with primary mood disorder subtypes including familial pure depressive disorder (FPDD) ${ }^{14}$ and nonpsychotic BD. ${ }^{15-18}$ Although abnormal amygdalar activation during task performance has been noted in many other psychiatric disorders, this abnormality of resting CBF and metabolism may be specific to certain forms of primary mood disorder. ${ }^{19}$ Furthermore, amygdalar activity as measured by CBF and GLC metabolism has been shown to correlate positively with both depression severity ${ }^{16,17,20}$ and susceptibility to depressive relapse. ${ }^{21}$

A number of studies have demonstrated increased amygdalar responses in activation paradigms for those with mood disorders. ${ }^{22-24}$ Interestingly, it has recently been reported that healthy carriers of the short (s) allele of the functional promoter polymorphism for the serotonin transporter gene (a finding that confers increased risk of depression) exhibit amygdalar hyperactivity. ${ }^{25-27}$

One significant function of the amygdala is to evaluate the emotional valence- be it positive $e^{28}$ or negative $e^{29-31}$ - of an experience. The amygdala also plays a key role in the acquisition and expression of emotionally charged memories as well as the emotional interpretation of social cues (reviewed by Drevets ${ }^{12}$ ). Thus, amygdalar dysregulation may have a direct phenomenological link with the emotionally biased interpretations of past, present, and future events and interactions frequently experienced in mood disorders. Extensive amygdalar projections to the hypothalamus and various brainstem nuclei may mediate many of the autonomic and somatic manifestations, social withdrawal, and fearful/defensive behaviors associated with depression (reviewed in Drevets 2001). ${ }^{10}$

The orbital cortex. Several studies have reported abnormally increased $\mathrm{CBF} /$ metabolism bilaterally in the posterior orbital cortex as well as in the left ventrolateral prefrontal cortex (VLPFC) and the anterior insula in unmedicated subjects with primary MDD. ${ }^{16,17,32-35}$ This finding is not specific for mood disorders, as it has been reported in various anxiety disorders as well as in experimentally induced sadness and anxiety. ${ }^{36}$ Although CBF/ metabolism seems to consistently be decreased in the remitted phase as compared with the depressed phase of MDD, ${ }^{17,37-39}$ an inverse relationship between depression severity and $\mathrm{CBF} /$ metabolism during the depressed phase of the illness has been reported. ${ }^{16,17}$ Studies of relatively mild, treatment-responsive depression in subjects with MDD or BD have shown increased orbital activity relative to healthy controls, whereas more severely depressed, treatment-resistant individuals with MDD or BD, as well as individuals with depression secondary to neurological disorders, showed no difference or had decreased activity of this region relative to controls. $^{12}$

Based on these observations, increased orbital CBF and metabolism in depression seems to be an endogenous compensatory mechanism. The orbital cortex and 
amygdala modulate each other's actions through direct reciprocal connections as well as through overlapping projections to the periaqueductal gray, hypothalamus, and striatum. ${ }^{40-42}$ Pyramidal cells from the orbital cortex are implicated in extinction of unreinforced responses to both rewarding and aversive stimuli. ${ }^{43-45}$ Humans and nonhuman primates with lesions of the orbital cortex perseverate in unreinforced behavioral responses and have difficulty switching intellectual strategies as reinforcement contingencies evolve. ${ }^{44,46-49}$ Thus, dysfunction of the orbital cortex and VLPFC may predispose individuals to the perseverative cognitions and emotional responses characteristic of depression.

The subgenual anterior cingulate. Metabolism and $\mathrm{CBF}$ of the subgenual anterior cingulate cortex (ACC) have repeatedly been measured to be decreased in unipolar and bipolar depression relative to control samples. ${ }^{50-52}$ Interestingly, CBF and metabolism in this region were reported to decrease further with successful antidepressant treatment. ${ }^{38,50,51}$ This observation was clarified by the finding of a left-lateralized volumetric reduction of the subgenual ACC in depressed subjects versus controls. ${ }^{51,53}$ In computer simulations that correct positron emission tomography (PET) data for the partial volume effect of gray matter volume reductions, the corrected subgenual metabolic activity in depressed subjects was increased relative to controls, ${ }^{54}$ and this hypermetabolism returned to normal levels with effective treatment. ${ }^{55}$ Even when uncorrected for partial volume averaging effects, subgenual ACC metabolism appears abnormally increased in manic subjects. ${ }^{12}$

Evidence from lesion studies in rats suggests that leftsided lesions of the subgenual PFC are associated with increased corticosterone secretion and sympathetic autonomic arousal in response to stress, whereas right-sided subgenual lesions had the opposite effect. ${ }^{12}$ Through its efferent projections to the ventral tegmental area (VTA) that act to increase dopamine (DA) release in the ventral striatum, the subgenual PFC also appears to play a role in evaluating the reward-related salience of stimuli. ${ }^{12,54}$ Thus, disturbances in this region may relate to disruptions in hedonic tone and motivation seen in depression and mania.

The dorsomedial prefrontal cortex. Based on studies of anticipated electrical shock in healthy human subjects, preclinical lesion models, and functional connectivity, the dorsomedial (DM) and dorsal anterolateral (DAL) PFC are thought to attenuate anxiety, defensive behavior, and cardiovascular responses to stress. ${ }^{42,56,57}$ Several PET studies have shown abnormally decreased CBF and metabolism in these regions in individuals with primary depression as well as in depressed subjects with Parkinson's disease. . $^{5,58-60}$

The dorsolateral prefrontal cortex and dorsal anterior cingulate cortex. Multiple regions of the dorso- lateral PFC (DLPFC) and dorsal ACC are activated in cognitive tasks related to working memory and attention. ${ }^{35}$ These regions show abnormal reductions in $\mathrm{CBF}$ and metabolism during depression ${ }^{54,61}$ and normalize during symptom remission. ${ }^{38,62}$ Drevets and Raichle ${ }^{36}$ hypothesize that activity in these cognitive circuits may be suppressed as a natural response to increased emotional processing. Although the altered activity in the DLPFC and dorsal ACC may not be centrally involved in the circuitry of mood disorders, it could account for some of the subtle disturbances of attention, memory, and visuospatial function manifested in these illnesses. ${ }^{63} \mathrm{Al}$ ternatively, a recent functional imaging study involving a social challenge paradigm found that healthy control subjects activated the DLPFC in response to hearing critical remarks, whereas fully remitted MDD subjects failed to activate this area. ${ }^{64}$ The possibility remains that a subtle trait-related dysfunction in the DLPFC could predispose to depression in at least a subset of those with mood disorders.

The mediodorsal thalamus. Depressed MDD and BD subjects manifest abnormal increases of metabolism and $\mathrm{CBF}$ in the left mediodorsal nucleus of the thalamus (MD). ${ }^{16,65-67}$ This nucleus has extensive connections with the amygdala as well as the orbital cortex, VLPFC, and subgenual PFC. ${ }^{43}$

The ventral striatum. The ventral striatum also has been noted to have extensive connections with the amygdala and the orbital, subgenual, and ventrolateral PFC. ${ }^{43}$ As mentioned above, it is also a key target of dopaminergic projections from the VTA. This VTA-accumbens circuit is a critical reward pathway of the brain. The relationship of this pathway to mood disorders requires further study, but it seems plausible that disturbances in this pathway would be related to abnormalities in hedonic tone and motivation, ${ }^{11}$ which are central features of mania and depression. This is supported by the finding of decreased striatal response to happy stimuli associated with level of anhedonia in depressed subjects ${ }^{68}$ as well as the observation of increased striatal activity in mania, ${ }^{69}$ a state characterized by hedonic excess.

\section{Volumetric studies in mood disorders}

Differences have not been detected between MDD and BD subjects and healthy controls in whole brain volume as well as in the volume of the PFC as a whole and many other brain regions. ${ }^{18,70}$ However, morphometric magnetic resonance imaging studies report a decrease in the gray matter volume of specific key areas of the orbital cortex, MPFC, DLPFC, mesial temporal lobe, and basal ganglia $^{71-75}$ (see FIG. 1). As mentioned above, the most prominent reduction is reported in the left (but not right) subgenual prefrontal cortex. An increase in the size of the third ventricle also has been consistently reported in patients with bipolar disorder, suggesting volumetric re- 
duction of the thalamus and hypothalamus (reviewed in Beyer et al., 2004; ${ }^{76}$ Manji et al., 2003 ${ }^{77}$ ).

These volumetric changes may appear early in the course of illness. Dickstein et al. $(2005)^{76}$ noted reductions in the left DLPFC and, to a lesser extent, in the left accumbens and left amygdala among a group of $20 \mathrm{BD}$ subjects. Amygdalar volume reduction has been reported in a group of 20 children and adolescents with MDD (Rosso et al., 2005). ${ }^{77}$ This finding could possibly precede symptom onset because decreased gray matter of the amygdala and perigenual cingulate has also been reported in short allele carriers for the functional promoter polymorphism of the serotonin transporter gene. ${ }^{26}$

\section{Histopathological studies in mood disorders}

Guided by these functional and structural imaging findings, postmortem histopathological studies have shown abnormal reductions in cortex volume, glial cell counts, and/or neuron size in the subgenual PFC, orbital cortex, dorsal anterolateral PFC, amygdala and in basal ganglia and dorsal raphe nuclei ${ }^{78-80}$ (see FIG. 2). It is not known whether these deficits constitute developmental abnormalities that may confer vulnerability to abnormal mood episodes, compensatory changes to other pathogenic processes, or the sequelae of recurrent mood episodes per se. This marked reduction in glial cells is particularly intriguing in light of growing appreciation of the critical role played by glia in modulating neuronal synaptic neurotransmission, plasticity, and regeneration and contributing to various pathological processes that impair brain function. ${ }^{81-86}$ Abnormalities of glial function could thus prove integral to the impairments of structural plasticity and overall pathophysiology of mood disorders.

\section{Presumptive mood disorder circuits}

These findings have led to the identification of two critical circuits involved in mood disorders. ${ }^{10,12,16}$ The first of these, the limbic-thalamic-cortical (LTC) circuit, comprises the amygdala, the mediodorsal thalamus, and the orbital and medial PFC. These regions are all interconnected by excitatory glutamatergic projections. ${ }^{43} \mathrm{~A}$ second circuit, the limbic-cortical-striatal-pallidal-thalamic (LCSPT) circuit, includes the components of the LTC circuit as well as related areas of the striatum and pallidum $^{87}$ (see FIG. 1). A number of more recent studies also support the involvement of these regions and circuits. ${ }^{67,88-96}$ In both of these circuits, pathologically increased amygdalar activity drives increased activity in the PFC and medial thalamus.

The involvement of these circuits in mood disorders is supported not only by imaging findings in primary mood disorders, but also by the increased frequency of mood disturbance in various neurological conditions (e.g., Huntington's and Parkinson's diseases, strokes, and tumors) that involve lesions in these areas. ${ }^{97-99}$ Con- versely, surgeries such as subcaudate tractotomy, prefrontal/limbic leukectomy, and anterior cingulotomy that have been used to alleviate intractable depression affect these circuits by disrupting projections from the amygdala to the ACC or the striatum. ${ }^{100-106}$

\section{Effects of current and experimental treatments in modulating affective circuits}

Effective treatment with antidepressant medication has been associated with modulation of activity in the circuits described above. ${ }^{107-109}$ A number of studies have demonstrated that effective treatment with antidepressant medication consistently decreases $\mathrm{CBF}$ and metabolism in the amygdala and orbital/insular cortex. ${ }^{59}$ Decreasing amygdalar hyperactivity may be a primary effect of these medications, which would then allow the orbital cortex to "relax."12 The effects on neural circuitry of various antidepressant medications as well as other forms of proven or potential antidepressant treatment are reviewed in Table 1.

The dopamine agonist pramipexole is the only treatment for which there are two positive controlled trials in acute bipolar depression. ${ }^{10,111}$ PET ${ }^{18}$ F-fluorodeoxyglucose scans of cerebral glucose metabolism were acquired in 15 subjects with bipolar II depression (BD II) at baseline and at the end of a 6-week double-blind, placebocontrolled add-on clinical trial of pramipexole. Pramipexole treatment reduced metabolic activity in some regions where metabolism was abnormally elevated in the baseline depressed condition, such as the ventrolateral and anteromedial PFC, consistent with the effects of other somatic antidepressant treatments. In contrast to functional imaging studies of conventional antidepressant medications, pramipexole did not alter metabolism in the amygdala but did increase activity in the premotor cortex, hippocampus, posterior cingulate cortex, and superior temporal gyrus. ${ }^{112}$

For electroconvulsive therapy (ECT), the most effective acute depression treatment to date, good clinical response is associated with electrode placement over the $\mathrm{PFC}^{113}$ and with relatively decreased activity after treatment in the PFC, anterior cingulate, and temporal and parietal cortices. ${ }^{39,114}$

Cognitive behavioral therapy (CBT) and interpersonal therapy (IPT), two forms of psychotherapy studied for efficacy in the treatment of depression, have effects on affective circuitry that are distinct from those of antidepressant medication. ${ }^{37,115,116}$ A "top-down" mechanism has been postulated in which these therapies may enhance function of the orbital cortex/anterior insula and other cortical regions to more effectively attenuate dysregulated limbic activity. ${ }^{12,116}$ These findings support the hypothesis that it is an imbalance within these circuits, rather than any specific directional disturbance in a sin- 
TABLE 1. Effects of Various Standard and Experimental Antidepressant Treatments on Regional Cerebral Blood Flow/Metabolism

\begin{tabular}{|c|c|c|c|c|c|}
\hline Authors & $\begin{array}{l}\text { Imaging } \\
\text { Modality }\end{array}$ & $\begin{array}{l}\text { Treatment Interval } \\
\text { Between Scans }\end{array}$ & Imaging Paradigm & $\begin{array}{l}\text { Antidepressant } \\
\text { Treatment }\end{array}$ & Regional Changes Post- $v s$ Pretreatment \\
\hline Anand et al. $(2005)^{107}$ & fMRI & 6 weeks & $\begin{array}{l}\text { Neutral, positive } \\
\text { and negative } \\
\text { pictures }\end{array}$ & Sertraline & $\uparrow$ Correlation of ACC and limbic regions \\
\hline Bauer et al. $(2005)^{210}$ & FDG PET & 7 weeks & Auditory CPT & $\begin{array}{l}\text { Adjunctive high-dose } \\
\text { L-T4 }\end{array}$ & $\begin{array}{l}\downarrow \text { BL SG \& PG ACC, VLPFC, Lat Orb C, A Ins } \\
\text { R SGACC, L Thal, R Amyg, R HC, R D/V St. } \\
\& \text { vermis }(\downarrow \text { L Thal, L Amyg, L HC, \& L V } \\
\text { St correlate w/ } \downarrow \text { depression scores })\end{array}$ \\
\hline Brody et al. $(2001)^{115}$ & FDG PET & 12 weeks & Rest & $\begin{array}{l}\text { Paroxetine } \\
\text { IPT }\end{array}$ & $\begin{array}{l}\downarrow \text { PG ACC \& VLPFC } \\
\downarrow \text { PGACC, Inc L ant insula }\end{array}$ \\
\hline Buchsbaum et al. $(1997)^{50}$ & FDG PET & 10 weeks & CPT & Sertraline & $\downarrow$ PG ACC, VMPFC \\
\hline Cohen et al. $(1992)^{34}$ & FDG PET & $\geq 10 \mathrm{~d}$ & Aud discrim task & Phototherapy & $\downarrow$ medial orbital C \\
\hline $\begin{array}{l}\text { Drevets and Raichle } \\
(1992)^{240}\end{array}$ & CBF PET & 8 weeks & Rest, eyes closed & Desipramine & $\downarrow$ VLPFC/lat orbital C \\
\hline Drevets et al. (2002) & FDG PET & 4 weeks@ opt dose & Rest, eyes closed & Sertraline & $\downarrow$ L Amyg, L SG ACC \\
\hline Drevets et al. $(2002)^{242}$ & FDG PET & & Rest, eyes closed & Citalopram & $\begin{array}{l}\downarrow \text { LAmyg, VSt, MThal, Pins } \\
\downarrow \text { BL SG \& PG ACC, VLPFC, Lat Orb C, A Ins }\end{array}$ \\
\hline Fu et al. $(2004)^{108}$ & fMRI & 8 weeks & Sad faces & Fluoxetine & $\begin{array}{l}\downarrow \text { L Amyg, V St, \& frontopar C } \\
\uparrow \text { dynamic range in PFC }\end{array}$ \\
\hline Goldapple et al. $(2004)^{116}$ & FDG PET & 15-20 sessions & Rest, eyes closed & CBT & $\begin{array}{l}\downarrow \text { DL, V, and MPFC } \\
\uparrow \mathrm{HC}, \mathrm{DCC}\end{array}$ \\
\hline Holthoff et al. $(2004)^{243}$ & FDG PET & 12 weeks remitted & Rest, eyes closed & $\begin{array}{l}\text { Citalopram or } \\
\text { mirtazapine }\end{array}$ & $\begin{array}{l}\downarrow \text { L PFC, ant temp \& ACC } \\
\downarrow \text { BL Thal, Put, \& Crbllum }\end{array}$ \\
\hline Kennedy et al. $(2001)^{244}$ & FDG PET & 6 weeks & Rest, eyes open & Paroxetine & $\begin{array}{l}\downarrow \text { BL insula, R HC/paraHC } \\
\uparrow \text { PGACC, DLPFC, VLPFC, MPFC, par C }\end{array}$ \\
\hline Mayberg et al. $(2000)^{130}$ & FDG PET & 6 weeks & Rest & Fluoxetine & $\begin{array}{l}\downarrow \text { A Ins, SGACC, HC, Pal } \\
\uparrow \text { L VLPFC, DLPFC, DACC, PCC, par C, BS }\end{array}$ \\
\hline Mayberg et al. $(2005)^{245}$ & CBF PET & $\begin{array}{l}3 \text { and } 6 \text { months } \\
\text { after baseline }\end{array}$ & Rest, eyes closed & DBS (Cg25WM) & $\begin{array}{l}\downarrow \text { SGACC, HT, MPFC, orb C } \\
\uparrow \text { DLPFC, BS, DCC }\end{array}$ \\
\hline Nobler et al. $(1994)^{39}$ & Xe 133 & $\begin{array}{l}\text { ECT course }+1 \\
\text { week }\end{array}$ & Rest, eyes closed & ECT & $\downarrow \mathrm{L}$ VLPFC in responders \\
\hline Nobler et al. $(2000)^{246}$ & Xe 133 & 6-9 weeks & Rest, eyes closed & $\begin{array}{l}\text { Nortriptyline or } \\
\text { sertraline }\end{array}$ & $\downarrow$ L VLPFC in responders \\
\hline Nobler et al. $(2001)^{114}$ & FDG PET & $\begin{array}{l}\text { Mean } 13.7 \pm 6.4 \\
\text { treatments }\end{array}$ & $\begin{array}{l}\text { Uniform visual } \\
\text { stimulus }\end{array}$ & ECT & $\begin{array}{l}\downarrow \text { L VLPFC, SGPFC, PCC, frontopar C, L M } \\
\text { temp C }\end{array}$ \\
\hline Nofzinger et al. $(2001)^{247}$ & FDG PET & Mean $11 \pm 1$ weeks & Awake/REM sleep & Bupropion & $\downarrow$ ACC, MPFC, \& R ant insula \\
\hline Saxena et al. $(2002)^{248}$ & FDG PET & $8-12$ weeks & Rest, eyes open & Paroxetine & $\begin{array}{l}\downarrow \text { L VLPFC, BL orbital C } \\
\uparrow \mathrm{R} \mathrm{St}\end{array}$ \\
\hline Smith et al. $(1999)^{249}$ & FDG PET & $\begin{array}{l}1 \text { day, } 2 \text { days } \\
2 \text { weeks }\end{array}$ & СРT & $\begin{array}{l}\text { Sleep deprivation } \\
\text { Paroxetine }\end{array}$ & $\begin{array}{l}\downarrow \text { R VLPFC, R PGACC } \\
\downarrow \text { BL PGACC, L DLPFC }\end{array}$ \\
\hline Wu et al. $(1992)^{18}$ & FDG PET & 1 day & CPT & Sleep deprivation & $\downarrow$ ACC in responders \\
\hline Zarate et al. $(2005)^{112}$ & FDG PET & 6 weeks & Rest, eyes closed & Pramipexole & $\begin{array}{l}\downarrow \text { L VL \& BL AMPFC, L inf par C } \\
\uparrow \text { PCC, HC, A Ins. Sup temp g }\end{array}$ \\
\hline
\end{tabular}

$\mathrm{fMRI}=$ functional magnetic resonance imaging; FDG = fluorodeoxyglucose; Xe $=$ Xenon; opt. = optimum; CPT = continuous performance task; L-T4 = Levothyroxine; R = right; SG $=$ subgenual; $\mathrm{L}=$ left; Thal = thalamus; Amyg = amygdala $\mathrm{HC}=$ hippocampus; $\mathrm{D}=$ dorsal; $\mathrm{V}=$ ventral; $\mathrm{St}=$ striatum; $\mathrm{PG}=$ pregenual; $\mathrm{VL}=$ ventrolateral; $\mathrm{PFC}=$ prefrontal cortex; $\mathrm{A}=$ anterior; Ins = insula; $\mathrm{VM}=$ ventromedial; $\mathrm{M}=$ medial; Lat = lateral; Orb = orbital; $\mathrm{C}=$ cortex; $\mathrm{P}=$ posterior; $\mathrm{BL}=$ bilateral; $\mathrm{Par}=$ parietal; $\mathrm{DL}=\mathrm{dorsolateral} ; \mathrm{DCC}=$ dorsal cingulate cortex; Temp = temporal; Put $=$ putamen; Crblm = cerebellum; ParaHC $=$ parahippocampal gyrus; Pal $=$ pallidum; PCC $=$ posterior cingulate cortex; $\mathrm{BS}=$ brainstem; HT = hypothalamus; $\mathrm{AM}=$ anteromedial; Inf = interior; Sup = superior; $\mathrm{g}=$ gyrus. 
gle region, that provides a neural substrate for mood dysregulation.

Magnetic seizure therapy (MST), an experimental technique using a magnetic field to induce a seizure, is currently being investigated in the treatment of depression by Lisanby et al. ${ }^{117}$ They have reported some preliminary evidence that MST may have fewer cognitive side effects than ECT. They further hypothesize that, based on intracerebral electrode studies in nonhuman primates and the fact that magnetic fields are not impeded by skull and soft tissues as is electricity, MST (if proven effective) may represent an improvement over ECT as the seizure can be more directly targeted at affective circuits and therefore may have fewer cognitive side effects than ECT.

Repetitive transcranial magnetic stimulation (rTMS) has been reported to have a variety of effects on activity within affective circuits. ${ }^{118}$ Results of clinical trials have been mixed. Whereas some studies have shown antidepressant effects, ${ }^{118,119}$ rTMS remains an investigational technique in the United States. Sapolsky ${ }^{120}$ notes that neurogenesis (which has been shown to be induced by antidepressant medications and ECT) is not induced by rTMS. Further research is needed to address various parameters of optimal treatment delivery before the question of clinical efficacy for rTMS can be definitively answered.

Vagus nerve stimulation (VNS), previously approved for treatment of refractory epilepsy, has recently been approved in the United States for use in treatment-resistant mood disorders. A number of functional imaging studies have demonstrated that VNS is associated with altered activity of the thalamus and hypothalamus, amygdala and related limbic structures, orbital cortex, basal ganglia, cerebellum, and medulla. ${ }^{121,122}$ Although initial open trials suggested a substantial acute and long-term benefit in treatment-resistant depression, ${ }^{123,124}$ a larger randomized controlled trial failed to show acute efficacy. ${ }^{125}$ Evidence exists for modest efficacy at long-term (12 months) follow-up. ${ }^{126,127}$

In recent years, chronic deep brain stimulation (DBS) in pathologically overactive neural circuits has been found to produce significant therapeutic benefits in those who suffer from Parkinson's disease. ${ }^{128,129}$ In a preliminary and uncontrolled yet intriguing experiment, Mayberg et al. ${ }^{130}$ applied high-frequency DBS to the subgenual cingulate (BA25) of six subjects with severely treatment-refractory depression. All six subjects experienced acute effects intraoperatively including an increased sense of well-being, interest, and calmness as well as an enhanced awareness of the physical surroundings. At months 2 through 4 after implantation, five of the six subjects had a greater than $50 \%$ improvement in their depressive symptoms. Four of these subjects maintained this response at 6 months after implantation. An- tidepressant response to DBS was associated by CBF decreases in BA25 and adjacent orbital cortex, anterior insula, hypothalamus, and medial frontal cortex (BA10) as well as CBF increases in DLPFC, dorsal anterior and posterior cingulate, premotor, and parietal (BA40) regions (as measured by PET at 3 and 6 months after implantation). As the mechanism of DBS has not been clearly delineated, it remains unclear whether this effect may have resulted from inhibition, stimulation, or disruption of the neural projections traversing and/or emanating from this area. ${ }^{131}$ The optimal site for DBS in the treatment of mood disorders remains to be determined. Jimenez et al. ${ }^{132}$ describe achieving good antidepressant effect in an individual with refractory MDD using DBS in the inferior thalamic peduncle, presumptively altering activity in thalamo-orbitofrontal pathways. ${ }^{106}$

Further advances in the understanding of neural circuitry abnormalities in mood disorders will allow us to refine current treatments and develop novel therapeutic strategies in these illnesses.

\section{2) IMPAIRMENTS OF CELLULAR RESILIENCE AND STRUCTURAL PLASTICITY: POTENTIAL PATHOGENIC MECHANISMS AND THERAPEUTIC TARGETS}

The therapeutic strategies discussed above appear to modulate, either directly or indirectly, abnormalities in affective circuits in those who suffer from mood disorders. Elucidation of the factors that originate and/or maintain aberrancy in these circuits will undoubtedly lead to more effective and better tolerated treatment approaches. Converging lines of evidence indicate that impairments of cellular plasticity and resilience may underlie the pathophysiology of mood disorders..$^{11,133-136}$ Here, we propose that disturbances in neural plasticity and cellular resilience are critical factors in precipitating and perpetuating disruption of the affective circuits discussed above (see FIG. 2). Furthermore, we hypothesize that novel treatment interventions that directly address impairments in plasticity and cellular resilience will both lead to improved clinical outcomes and also show normalization of activity in these circuits. In the remaining sections, we review such potential therapeutic targets.

\section{Stress and glucocorticoids modulate neural plasticity: implications for affective circuits}

Although mood disorders undoubtedly have a strong genetic basis, considerable evidence has shown that severe stressors are associated with a substantial increase in risk for the onset of mood disorders in susceptible individuals. ${ }^{132}$ Activation of the hypothalamic-pituitaryadrenal (HPA) axis seems to play a role in mediating these effects, as stress-induced neuronal atrophy is prevented by adrenalectomy. ${ }^{137,139}$ These observations are 


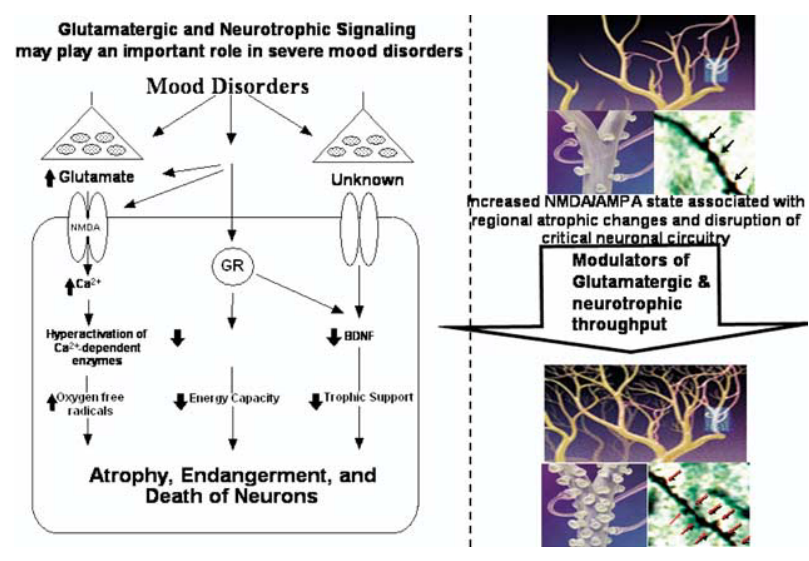

FIG. 2. The role of altered glutamatergic, neurotrophic, and glucocorticoid signaling in severe mood disorders. At left is depicted a broad overview of the pathways by which aberrant glutamate, glucocorticoid, and neurotrophic signaling may lead to atrophic changes. At right, a figurative representation of atrophic changes associated with an excessive glutamatergic state and the reversal of these changes via modulation of glutamatergic and neurotrophic signaling. $\mathrm{Ca}=$ calcium.

noteworthy with respect to the pathophysiology of major depressive disorders and bipolar disorder as a significant percentage of patients with mood disorders display some form of HPA axis activation, and the subtypes of depression most frequently associated with HPA activation are those most likely to be associated with hippocampal volume reductions. ${ }^{140,141}$ A positive correlation has been reported between left amygdala metabolism and stressed cortisol levels in both MDD and BD depressed subjects. ${ }^{15}$ This correlation could reflect either an effect of cortisol on amygdala function or an effect of amygdalar hyperactivity on CRH secretion. Corticosterone injection and exposure to acute and chronic stress have all been shown to disrupt dendritic morphology in the medial PFC. ${ }^{142-144}$

Another significant effect of stress and glucocorticoids is to reduce cellular resilience, rendering certain neurons more vulnerable to other insults such as ischemia, hypoglycemia, and excitatory amino acid toxicity ${ }^{134}$ The precise mechanisms by which glucocorticoids exert these deleterious effects are unclear, but likely involve the facilitation of glutamatergic signaling and inhibition of glucose transport. ${ }^{145}$ Decreased resilience of hippocampal neurons may also reflect the propensity for various stressors to decrease the expression of BDNF in this region. ${ }^{137,140}$

\section{The role of glutamate in disturbance of affective circuits}

Increased activation of NMDA as well as non-NMDA ionotropic glutamate receptors can result in neurotoxicity via overactivation of calcium-dependent enzymes and the generation of oxygen free radicals ${ }^{134}$ (see FIG. 3). Substantial evidence suggests that excessive glutamate transmission (which may be precipitated by stress) plays a central role in atrophy of CA3 pyramidal neurons in the hippocampus. Conversely, NMDA antagonists have been found to block hippocampal atrophy. ${ }^{138,140}$ As noted above, the projections in the LTC circuit are predominantly glutamatergic. The consistent overactivity seen in this circuit in mood disorders is likely to be associated with chronically elevated levels of glutamate in these regions. The anatomically selective distribution of neuropil decreases and the loss of glial cells in these areas (which are shown to be the primary uptake mechanism for glutamate from the synapse ${ }^{146}$ ) further support the involvement of glutamate toxicity in the disturbance of affective circuitry.

\section{Evidence suggesting that mitochondrial function may play a critical role in the pathophysiology and treatment of $\mathrm{BD}$}

Although the primary function of mitochondria is to convert organic materials into cellular energy in the form of ATP, mitochondria also play an important role in many important metabolic tasks, such as apoptosis, glutamate-mediated excitotoxic neuronal injury, cellular proliferation, and regulation of the cellular redox state. Mitochondrial diseases can affect any part of the body but are often seen in organs requiring high energy such as the brain, skeletal muscle, and the heart.

Kato and Kato ${ }^{147}$ had anticipated some of the recent developments in the field when they first proposed that mitochondrial dysfunction may play an important role in the pathophysiology of BD. Since then, there have been a number of human neuroimaging and postmortem brain studies, as well as preclinical molecular and cellular biologic studies that strongly support the argument that mitochondria may play a central role in the impairments of plasticity and cellular resilience manifest in BD. It is not our contention that $\mathrm{BD}$ is a classical mitochondrial disorder; thus, the vast majority of BD patients do not show the symptoms of classical mitochondrial disorders such as optic and retinal atrophy, seizures, dementia, ataxia, myopathy, exercise intolerance, cardiac conduction defects, diabetes, lactic acidosis, etc.

Magnetic resonance spectroscopy (MRS) has opened up a wide new avenue into in vivo brain chemistry, thus providing insight into the biochemical pathology of bipolar disorder. Studies using proton $\left({ }^{1} \mathrm{H}\right)$ MRS have identified changes in cerebral concentrations of $\mathrm{N}$-acetyl aspartate (NAA), glutamate/glutamine (Glx), cholinecontaining compounds, myo-inositol (mI), and lactate in bipolar subjects compared with normal controls. ${ }^{148}$ Studies using phosphorus $\left({ }^{31} \mathrm{P}\right)$ MRS have examined additional alterations in levels of phosphocreatine $(\mathrm{PCr})$, phosphomonoesters (PMEs), and intracellular $\mathrm{pH}$ (pHi). ${ }^{149}$ These seemingly disparate findings of increased lactate and GLX, decreased NAA, and decreased pHi in bipolar subjects suggest a shift away from oxidative 
phosphorylation toward glycolysis, leading to reduced total energy output and efficiency (reviewed in Stork and Renshaw 2005). ${ }^{148}$

Mitochondria play a critical role in maintaining calcium homeostasis. Excessive levels of calcium are a critical mediator of cell death cascades within neurons, necessitating homeostatic mechanisms to regulate intracellular calcium levels precisely. ${ }^{150}$ Interestingly, impaired regulation of $\mathrm{Ca}^{2+}$ cascades are among the most reproducible biological abnormalities described in $\mathrm{BD}$ research. ${ }^{151}$ The diverse findings seen on MRS may be directly related to alterations of calcium response and intracellular signaling systems in bipolar patients.

Most recently, Konradi and associates ${ }^{152}$ have undertaken an elegant series of postmortem brain microarray studies showing that nuclear mRNA coding for mitochondrial proteins was decreased in bipolar disorder in comparison with schizophrenia. These particular gene products are involved in regulating oxidative phosphorylation in the mitochondrial inner membrane and the ATP-dependent process of proteosome degradation [including subunits of complexes I [reduced nicotinamide adenine dinucleotide (NADH) dehydrogenase], IV (cytochrome $c$ oxidase), and V (ATP synthase)]. ${ }^{152}$

These cumulative findings of calcium dysregulation, abnormal nuclear mitochondrial gene expression, and shift from oxidative phosphorylation toward glycolysis are highly suggestive of underlying mitochondrial dysfunction in bipolar subjects (see FIG. 3). This has enormous potential for advancing the study of bipolar illness, particularly in terms of treatment. Investigations of mitochondria-based neurological disorders, including Huntington's disease, Parkinson's disease, amyotrophic lateral sclerosis (ALS), and mitochondrial cytopathies, is leading to the development of a number of therapies that target cellular energy dysfunction. If mitochondrial dysfunction is involved in the underlying pathology of $\mathrm{BD}$, such therapies may also prove beneficial in the treatment of bipolar disorder. Supplements such as coenzyme q10, carnitine nicotinamide, and lipoic acid have been studied in classical mitochondrial diseases and are worth investigating in $\mathrm{BD}$.

\section{Neurotrophic signaling cascades}

Neurotrophins comprise a family of proteins that mediate growth, differentiation, and survival of neurons, as well as the modulation of synaptic transmission and synaptic plasticity. The neurotrophin family now includes NGF, BDNF, neurotrophin-3 (NT-3), NT-4/5, and NT$6 .{ }^{153,154}$ Neurotrophins are initially synthesized as precursors (proneurotrophins), which serve as signaling molecules by interacting with the p75 pan-neurotrophin receptor $\left(\mathrm{p} 75^{\mathrm{NTR}}\right)$. Proneurotrophins are cleaved to produce mature neurotrophins, which promote neuronal survival and enhance synaptic plasticity by preferentially

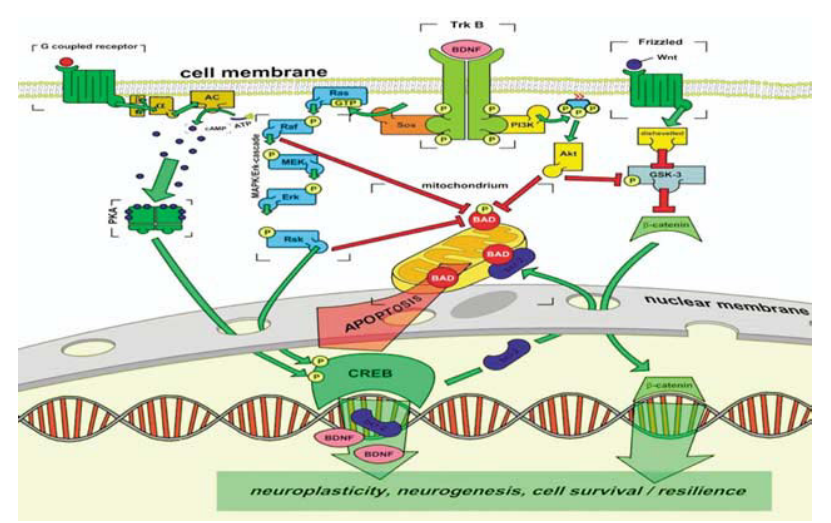

FIG. 3. Neuroplasticity and cellular resilience in mood disorders. This figure depicts the multiple influences on neuroplasticity and cellular resilience in mood disorders. Stress and depression likely contribute to impairments of cellular resilience by a variety of mechanisms, including reductions in the levels of BDNF, facilitating glutamatergic transmission via NMDA and non-NMDA receptors, and reducing the cells' energy capacity. Neurotrophic factors such as BDNF enhance cell survival by activating two distinct signaling pathways: the PI-3K pathway, and the ERK-MAP kinase pathway. One of the major mechanisms by which BDNF promotes cell survival is by increasing the expression of the major cytoprotective protein, $\mathrm{Bcl}-2$. The chronic administration of a variety of antidepressants increases the expression of BDNF, and its receptor TrkB. Lithium and VPA robustly upregulate the cytoprotective protein $\mathrm{Bcl}-2$. Lithium and VPA also inhibit GSK-3 $\beta$, biochemical effects shown to have neuroprotective effects. VPA also activates the ERK-MAP kinase pathway, effects that may play a major role in neurotrophic effects and neurite outgrowth. BDNF = trkB, tyrosine kinase receptor for BDNF; Bcl-2 and Bcl-x = antiapoptotic members of the $\mathrm{Bcl}-2$ family; $\mathrm{BAD}$ and $\mathrm{Bax}=$ proapoptotic members of the $\mathrm{Bcl}-2$ family; Ras, Raf, MEK, ERK = components of the ERKMAP kinase pathway; Rsk-2 = ribosomal S-6 kinase; ROS = reactive oxygen species. Adapted from Charney and Manji 2005.

binding to Trk receptor tyrosine kinases $\left(\mathrm{Trk}^{\mathrm{FL}}\right)$. There are several subtypes of Trk receptor kinases that are characterized by specific affinity for the different neurotrophins. NGF binds preferentially to TrkA, whereas BDNF and neurotrophin (NT)-4/5 show a high affinity for TrkB. NT-3, on the other hand, predominantly activates TrkC but can also bind to TrkB and TrkA, albeit with lower affinity. Interaction of mature neurotrophins with Trk receptors leads to cell survival, whereas binding of proNGF to $\mathrm{p} 75^{\mathrm{NTR}}$ leads to apoptosis. ${ }^{155}$ The functional importance of the pro region of BDNF was demonstrated in a recent study that investigated the consequences of a single nucleotide polymorphism in this region. This polymorphism is defined by replacement of valine ${ }^{156}$ with methionine and is associated with memory deficits and abnormal hippocampal function in humans. ${ }^{153}$

Neurotrophins are secreted constitutively or transiently, and often in an activity-dependent manner. Within the neurotrophin family, BDNF is a potent physiological survival factor implicated in a variety of pathophysiological conditions, including mood disorders. BDNF and other neurotrophic factors are necessary for 
the survival and function of neurons, implying that a sustained reduction of these factors could affect neuronal viability. ${ }^{157}$ However, somewhat less well appreciated is the fact that BDNF also has a number of acute effects on synaptic plasticity and neurotransmitter release, including facilitating the presynaptic release of acetylcholine, glutamate, and GABA. In this context, BDNF has been shown to potentiate both excitatory and inhibitory neuronal transmission, albeit via different mechanisms; BDNF strengthens excitation primarily by enhanced phosphorylation of the NMDA receptors and augmenting the amplitude of AMPA receptor-mediated miniature excitatory postsynaptic current (mEPSCs). ${ }^{158}$ It enhances inhibition by increasing the frequency of $\mathrm{mI}$ (inhibitory) PSCs and increasing the size of GABAergic synaptic terminals.

It is noteworthy that although endogenous neurotrophic factors have traditionally been viewed as increasing cell survival by providing necessary trophic support, it is now clear that their survival-promoting effects are mediated in large part by an inhibition of cell death cascades. Increasing evidence suggests that neurotrophic factors inhibit cell death cascades by activating the mitogen-activated protein (MAP) kinase signaling pathway and the phosphotidylinositol-3 kinase (PI-3K)/Akt pathway. One important mechanism by which the MAP kinase signaling cascades inhibit cell death is by increasing the expression of the antiapoptotic protein Bcl-2 (B cell lymphoma-2). ${ }^{157}$

Accumulating data suggest that not only is Bcl-2 neuroprotective, but it also exerts neurotrophic effects and promotes neurite sprouting, neurite outgrowth, and axonal regeneration. Moreover, a recent study demonstrated that severe stress exacerbates stroke outcome by suppressing Bcl-2 expression. ${ }^{159}$ In this study, the stressed mice expressed approximately $70 \%$ less Bcl-2 mRNA than unstressed mice after ischemia. Furthermore, stress greatly exacerbated infarct in control mice but not in transgenic mice that constitutively express increased neuronal Bcl-2. Finally, high corticosterone concentrations correlated with larger infarcts in wildtype mice but not in Bcl-2-overexpressing transgenic mice. Thus, enhanced $\mathrm{Bcl}-2$ expression appears to be capable of offsetting the potentially deleterious consequences of stress-induced neuronal endangerment, suggesting that pharmacologically induced upregulation of Bcl-2 may have considerable utility in the treatment of a variety of disorders associated with endogenous or acquired impairments of cellular resilience.

Overall, it is clear that the neurotrophic factors/MAP kinase/Bcl-2 signaling cascade plays a critical role in cell survival in the CNS (see FIG. 4), and that there is a fine balance maintained between the levels and activities of cell survival and cell death factors. Modest changes in this signaling cascade or in the levels of the Bcl-2 family of proteins (potentially due to genetic, illness, or insultrelated factors) may therefore profoundly affect cellular viability. We now turn to a discussion of the growing body of data suggesting that neurotrophic signaling molecules play important roles in the treatment of mood disorders.

\section{Antidepressants affect neurotrophic signaling within affective circuits}

A number of studies have investigated the possibility that the factors involved in neuronal atrophy and survival could be the target of antidepressant treatments. ${ }^{160,161}$ These studies demonstrate that one pathway involved in cell survival and plasticity, the cAMP response element binding protein (CREB) cascade is upregulated by antidepressant treatment. This group has also demonstrated that antidepressant treatment in vivo increases CREB phosphorylation and CRE-mediated gene expression in mouse limbic brain regions. ${ }^{162}$ Upregulation of CREB and BDNF occurs in response to several different classes of antidepressant treatments, indicating that the cAMPCREB cascade and BDNF are common postreceptor targets of these therapeutic agents.

In addition, upregulation of CREB and BDNF is dependent on chronic treatment over weeks, consistent with the time to onset of therapeutic effects of antidepressants. The importance of neurotrophic signaling in the mechanism of antidepressants is illustrated by findings that induced CREB overexpression in limbic areas ${ }^{163}$ as well as BDNF infusion into CA3 of the hippocampus ${ }^{164}$ or into the midbrain ${ }^{165}$ each produce antidepressant-like effects in animal models of depression. Indirect human evidence comes from studies showing increased hippocampal BDNF expression in postmortem brains of subjects with mood disorders treated with antidepressants at the time of death versus antidepressantuntreated subjects. ${ }^{166}$ Chronic administration of an atypical antidepressant, tianeptine, was reported to block the stressinduced atrophy of CA3 pyramidal neurons in adult male rats. ${ }^{167}$ Czeh et al. ${ }^{168}$ reported that stress-induced changes in brain structure and neurochemistry were counteracted by treatment with tianeptine.

\section{Neurotrophic effects of lithium and divalproex}

Lithium and divalproex have emerged as robust neuroprotective agents in preventing apoptosis of neurons. ${ }^{169,170}$ In addition to lithium's effects on a number of intracellular cascades, lithium also induces the expression of BDNF and subsequent activation of TrkB, the receptor for BDNF, in cortical neurons. The activation of BDNF/TrkB signaling is essential for the neuroprotective effects of this drug. In addition, lithium stimulates the proliferation of neuroblasts in primary cultures of CNS neurons. Lithium also shows neuroprotective effects in rodent models of diseases. In a rat model of stroke, postinsult treatment with lithium or valproate at therapeutic doses markedly reduces brain infarction and 
neurological deficits. This neuroprotection is associated with suppression of caspase-3 activation and induction of chaperone proteins such as heat shock protein 70 . In a rat model of Huntington's disease (HD) in which an excitotoxin is unilaterally infused into the striatum, both long- and short-term pretreatment with lithium reduces DNA damage, caspase-3 activation, and loss of striatal neurons. This neuroprotection is associated with upregulation of Bcl-2. ${ }^{171}$

Brain imaging studies provide evidence that lithium exerts neurotrophic effects in the human brain in vivo. Proton magnetic resonance spectroscopy has been used to show that total gray-matter content in the human brain of $\mathrm{N}$ acetylaspartate (NAA, a putative marker of neuronal variability and function ${ }^{172,173}$ ) were significantly increased after 4 weeks of lithium treatment. ${ }^{174}$ In a longitudinal highresolution volumetric MRI study in well-characterized, medication-free bipolar depressed subjects (Moore et al., submitted), total brain gray matter (GM), prefrontal GM, and left subgenual GM were determined at baseline and after 4 weeks of blinded lithium treatment. ${ }^{175}$ Significant increases in total brain GM in bipolar subjects were observed after chronic lithium administration. The regionspecific analyses revealed significant differences between responders $(>50 \%$ decrease in HAM-D) and nonresponders; only responders showed increases in GM in the prefrontal cortex and left subgenual prefrontal cortex. The time frame of these effects and their relationship with clinical response suggest that pharmacologic strategies to enhance cellular plasticity and resilience may have utility not only for the long-term course of the illness, but also for treatment of the acute illness.

\section{Sleep deprivation}

Sleep deprivation is the only known therapeutic maneuver that appears to alter mood in a majority of both bipolar and unipolar patients in a matter of hours. Sleep deprivation is also capable of triggering switches into mania/hypomania, and therefore the study of the potential cellular mechanisms by which sleep deprivation may bring about these rapid behavioral changes in patients with mood disorders may be particularly informative. There is now incontrovertible evidence that the expression of selected critical genes varies dramatically during sleep and waking events, which likely plays a major role in regulating various and long-term neuroplastic events. ${ }^{176}$ mRNA differential display, microarray, and biochemical studies have shown that short-term sleep deprivation is associated with an immediate 1) increase in levels of pCREB (the active form of this transcription factor); 2) increase in expression of BDNF; and 3) increase in expression of BDNF's receptor, TrkB.

As discussed previously, these are precisely the plasticity-related molecules whose expression is increased by chronic antidepressant treatment. In an extension of the gene expression studies, Cirelli and Tononi ${ }^{176}$ hypothesized that a key factor responsible for the induction of the plasticity genes might be the level of activity of the neuromodulatory noradrenergic and serotonergic systems. Both of these systems project diffusely to most of the brain, where they regulate gene expression, and are only quiescent during rapid eye movement (REM) sleep.

During normal sleep, the noradrenergic system, represented by the locus ceuruleus (LC), is quiescent during REM sleep. During sleep deprivation, the noradrenergic system is activated at a time when it is normally quiet. The activity of the noradrenergic system in a different postsynaptic environment than normal may be the key factor in inducing physiological changes that result in mood elevation in depressed patients. One possible effect of an active noradrenergic system during a time when it is normally quiescent is an effect on gene expression. For example, the CREB-BDNF genes, which are known to be involved with neuroplasticity, may increase their expression levels in response. Increases in the expression of these genes have been shown to be downstream effects of antidepressants. Thus, a more rapid increase in their expression by manipulations of the noradrenergic system may underlie the rapid antidepressant response to sleep deprivation. ${ }^{177}$

\section{Lithium and glycogen synthase kinase-3}

The relevance of glycogen synthase kinase-3 (GSK-3) to the pathophysiology and treatment of mood disorders became apparent following the seminal observation that lithium directly inhibits this enzyme. ${ }^{178,179}$ Recent animal behavioral data have shown that manipulation of the GSK-3 signaling cascade produces both antimanic and antidepressant effects in pharmacologic and genetic models of depression and mania. ${ }^{180}$ GSK-3, a component of many signaling pathways with multiple cellular targets $^{181}$ (see FIG. 4) regulates multiple cellular processes such as glycogen synthesis, gene transcription, events related to synaptic plasticity, apoptosis, and the circadian cycle. ${ }^{180,182}$ In addition to lithium, serotonin and catecholamines, as well as a variety of other treatments known to have effects on mood including valproate, lamotrigine, antidepressants, antipsychotics, gonadal steroids, amphetamines, and electroconvulsive seizures, modulate GSK-3 either directly or indirectly within key areas of the brain implicated in BD. Thus, GSK-3 is situated at a nexus of multiple neurotransmitter and signaling cascades as well as neuroanatomic circuits putatively involved in BD.

GSK-3 is a major regulator of apoptosis and cellular plasticity/resilience. Generally, increased activity of GSK-3 is proapoptotic, whereas inhibition of GSK-3 attenuates or prevents apoptosis. ${ }^{180,181}$ Preclinical studies using animal models of Alzheimer's disease have shown that GSK-3 inhibition had beneficial effects on 


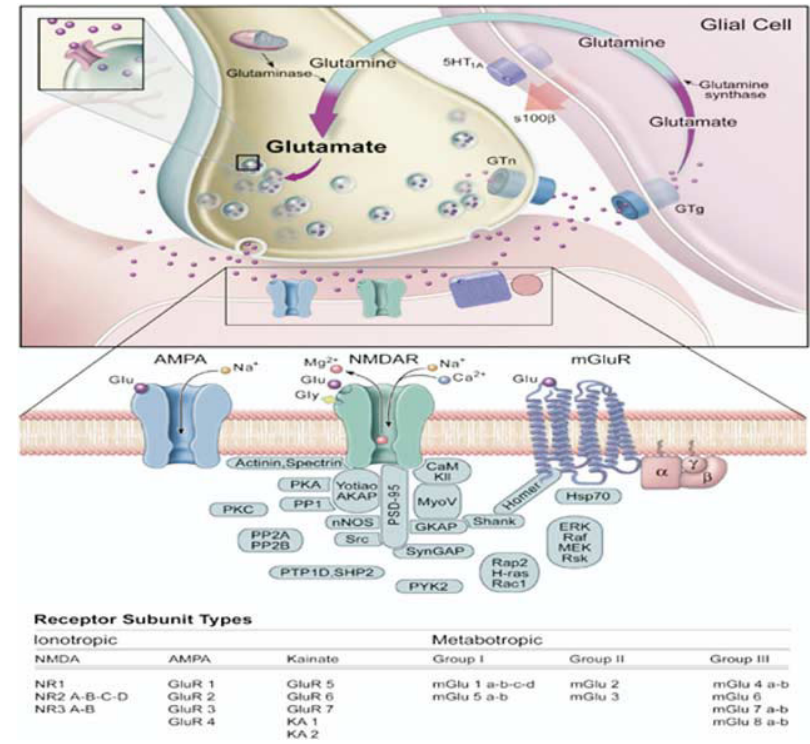

FIG. 4. Glutamatergic system. This figure depicts the various regulatory processes involved in glutamatergic neurotransmission. Once released from the presynaptic terminal, glutamate is able to bind to numerous excitatory amino acid (EAA) receptors, including both ionotropic (e.g., NMDA, AMPA) and metabotropic receptors. Glutamate has its action terminated in the synapse by reuptake mechanisms using distinct GLU transporters (GLUTs), which exist not only on presynaptic nerve terminals, but also on astrocytes. Indeed, current data suggest that astrocytic Glu uptake may be more important for clearing excess Glu, raising the possibility that astrocytic loss (as has been documented in mood disorders) may contribute to deleterious GLU signaling. It is now known that there are a number of important intracellular proteins that are able to alter the function of glutamate receptors (see diagram). Also, growth factors like GDNF and $\mathrm{S} 100 \beta$, secreted from glia, have been demonstrated to exert a tremendous influence on glutamatergic neurons and synapse formation. 5- $\mathrm{HT}_{1 \mathrm{~A}}$ receptors, noted to be regulated by antidepressant agents, modulate the release of $\mathrm{S} 100 \beta$. Adapted with permission from Cooper et al., 2001, Manji et al., 2003a.

the $\beta$-amyloid and hyperphosphorylated tau cascades implicated in Alzheimer's disease. ${ }^{183}$ Emerging data suggest that BD is associated with cell loss/atrophy, and there are now considerable data demonstrating that lithium exerts neuroprotective effects; these effects are believed to be mediated in large part by inhibition of GSK-3 and upregulation of Bcl-2. ${ }^{184,185}$ Administration of dexamethasone has been shown in osteoblast cultures to oppose the downstream effects of GSK-3 inhibition on $\beta$-catenin and TCF/LEF-mediated transcription. ${ }^{186,187}$ If this finding holds true in the brain, it would represent an interesting relationship between the HPA axis and $\beta$-catenin/GSK-3.

As described above, abnormal energy metabolism in the LTC and LCSPT circuits has been noted in those with mood disorders. The central role played by GSK-3 in the insulin/IGF-I signaling pathway may offer a potential pathophysiological mechanism as well as a possible treatment target for abnormal cellular metabolism in affective illness.
Given their potential therapeutic effects in mood disorders as well as Alzheimer's disease and other neurodegenerative disorders, novel CNS-penetrant GSK-3 inhibitors are actively being developed by many pharmaceutical companies. ${ }^{188-190}$ Examples are summarized in Table 2. Inositol monophosphatases may represent another important target for lithium's actions; however, at this point, there are no selective CNS-penetrant IMPases available for human use.

\section{Valproate, histone deacetylase, and epigenetic regulation of neuroprotection}

Valproate, a mainstay of mood stabilization treatment in $\mathrm{BD}$, has recently been shown to be an inhibitor of histone deacetylase (HDAC). Acetylation of histones, by decreasing their affinity for DNA, is a significant epigenetic regulator of gene expression. It is possible that the therapeutic effects of valproate may in part be related to this important epigenetic mechanism. In support of this, valproate and several other HDAC inhibitors have shown neuroprotective effects in animal models of cerebral ischemia, ${ }^{190,191}$ Parkinson's disease, ${ }^{192}$ and Huntington's disease. ${ }^{193,194}$ Weaver and associates ${ }^{195}$ demonstrated in rat pups that behaviorally programmed, persistent epigenomic alterations of a glucocorticoid receptor gene promoter in the hippocampus induced by certain styles of maternal behavior could be reversed by central infusion of an HDAC inhibitor. Tremolizzo and colleagues ${ }^{196}$ found that hypermethylation of the reelin promoter and subsequent decrease of reelin expression, which have been suggested by recent studies to be present in BD and schizophrenia patients, were prevented by valproate in doses inhibitory to HDACs. Thus, HDAC inhibitors represent a class of agents that may be available for clinical trials in mood disorders (see Table 2) as well as a theoretical model by which other agents that target epigenetic regulation mechanisms potentially involved in mood disorder pathogenesis may be pursued.

\section{Protein kinase $\mathrm{C}$ signaling cascade: a shared biochemical target for the actions of chronic lithium and valproate}

Lithium and valproate share similar effects on the protein kinase $\mathrm{C}$ (PKC) signaling cascade that are likely relevant to their antimanic profile. ${ }^{197} \mathrm{PKC}$, a group of calcium and phospholipid-dependent enzymes, plays a pivotal role in cell signaling systems, plasticity, and long-term alterations in gene expression. A considerable amount of biochemical data, including evidence of changes in PKC and its substrates in bipolar patients and in PKC signaling pathways after treatment with lithium or valproate, ${ }^{197}$ supports the potential involvement of PKC in the pathophysiology and treatment of BD.

Recently, Birnbaum and associates ${ }^{198}$ demonstrated that excessive activation of PKC (including by stress) 
TABLE 2. Putative Plasticity-Enhancing Candidate Drugs for the Treatment of Mood Disorders

\begin{tabular}{|c|c|}
\hline Class & Drug/Compound* \\
\hline GSK-3 inhibitors & $\begin{array}{l}\text { Zinc, indirubines, maleimides, hymenialdesine, paullones, } \\
\text { thiazolidines, azole derivatives }\end{array}$ \\
\hline HDAC inhibitors & $\begin{array}{l}\text { Small-molecular weight carboxylates (butyrate, valproic } \\
\text { acid, sodium phenylbutyrate), hydroxamic acids } \\
\text { (trichostatin A [TSA]), suberoylanilide (SAHA) and } \\
\text { LAQ-824, epoxyketones (2-Amino-8-oxo-9,10- } \\
\text { epoxydecanoic acid [AOE] and trapo xin B, cyclic } \\
\text { peptides (depsipeptide, apicidin), hybrid molecules } \\
\text { (CHAP31, CHAP50) }\end{array}$ \\
\hline PKC inhibitors & $\begin{array}{l}\text { Tamoxifen, LY33531, ruboxistaurin, rottlerin, } \\
\text { indolocarbazoles, PKC412, bisindolylmaleimides, } \\
\text { balanol, indolylindazolylmaleimides, aprinocarsen }\end{array}$ \\
\hline \multicolumn{2}{|l|}{ Glutamatergic modulators } \\
\hline Inhibitor of glutamate release and AMPA potentiator & Riluzole \\
\hline NMDA antagonists & Ketamine, memantine, felbamate, zinc \\
\hline AMPA receptor potentiators & $\begin{array}{l}\text { Benzoylpiperidone (aniracetam), benzoylpyrrolidines } \\
\text { (Ampakines), arylpropylsulfonames (LY392098, } \\
\text { LY451616), S18986 }\end{array}$ \\
\hline mGluR & Group III mGluR agonists \\
\hline \multicolumn{2}{|l|}{ HPA axis modulators } \\
\hline Glucocorticoid synthesis inhibitors & Ketoconazole, aminogluthethimide, metyrapone \\
\hline GR II antagonist & $\begin{array}{l}\text { Mifepristone (RU-486), ORG 34517, ORG 34850, ORG } \\
\text { 34116, AL082D06, cyproterone acetate }\end{array}$ \\
\hline $\begin{array}{l}\text { Hydrocortisone } \\
\text { DHEA }\end{array}$ & \\
\hline CRF 1R antagonist & $\begin{array}{l}\text { Peptides (astressin, } \alpha \text {-helCRF), small molecule non- } \\
\text { peptides (CP-154526, antalarmin, DMP-695, DMP-696, } \\
\text { CRA-1000, SSR-125543, NBI 35965, NBI 27914) }\end{array}$ \\
\hline PDE4 inhibitor & Rolipram \\
\hline Bcl-2 enhancer & Pramipexole \\
\hline Mitochondrial enhancer & $\begin{array}{l}\text { Coenzyme q10, carnitine nicotinamide, lipoic acid, } \\
\text { mitoquinone, uridine/RG } 2133\end{array}$ \\
\hline
\end{tabular}

$\mathrm{CRF}=$ corticotrophin releasing factor; DHEA $=$ dihydroepiandrosterone. $*$ Drugs/compounds are at different stages of development; some may have been tested for proof-of-concept rather than for clinical use and others at this time may not be able to be used on a long-term basis because of treatment-limiting side effects. Modified from Zarate et al. 2005.

dramatically impaired the cognitive functions of the prefrontal cortex, whereas inhibition of PKC (including indirectly with mood stabilizers) preserved cognitive function. Pharmacological inhibition of PKC results in many behavioral changes similar to the ones induced by mood stabilizers including attenuation of hyperactivity, risktaking behavior and hedonic drive (Einat and Manji, submitted). ${ }^{199}$ Psychostimulants, which are capable of triggering manic episodes in susceptible individuals and induce manic-like behaviors in rodents, are known to activate PKC. These data suggest that PKC modulation plays a critical role in the treatment of mania.

Based on these findings, a preliminary study suggested that the PKC inhibitor tamoxifen has antimanic properties. ${ }^{200}$ Larger double-blind placebo-controlled studies of tamoxifen are currently in progress. Selective PKC inhibitors, currently in late stage clinical trials to treat diabetic complications, ${ }^{182}$ have potential utility in the treatment of BD (see Table 2).

\section{Thyroid hormone: neurotrophic effects in critical affective circuits}

Significant evidence suggests a relationship of thyroid hormone with affective disorders. ${ }^{201}$ The clinical efficacy of adjunctive thyroxine (T4) or triiodothyronine (T3) in the treatment of refractory unipolar and bipolar mood disorders has been fairly well established. ${ }^{202}$ Cole et al. ${ }^{203}$ observed in patients with bipolar depression that lower pretreatment thyroid activity (albeit within the normal range) predicted a worse response to treatment. Frye et al. ${ }^{204}$ noted an inverse association between serum free T4 levels and increased mood instability and depression among bipolar patients maintained on lithium.

Mechanisms by which thyroid hormone may exert its thymoleptic effects are not clearly elucidated. Most research related to this question has been focused on the noradrenergic and serotonergic systems. ${ }^{205,206}$ More recently, evidence has emerged that thyroid hormone has neurotrophic effects. T3 exerts its actions through bind- 
ing to thyroid hormone receptors located in the nucleus. These receptors have been reported to be particularly dense in key limbic regions such as the amygdala and hippocampus. ${ }^{207,208}$ The T3-receptor complex acts to increase expression of target genes, which are known to include neurotrophins and their receptors, transcription factors, and proteins involved in intracellular signaling. As reviewed in Manji and colleagues, ${ }^{134}$ thyroid activity in rats influences the balance between $\mathrm{G} \alpha \mathrm{i}$ and $\mathrm{G} \alpha$ s (the $\mathrm{G}$ proteins that inhibit and stimulate, respectively, adenylyl cyclase) in a variety of tissues, including the brain. Specifically, hypothyroid states have been shown to decrease cAMP signaling, whereas thyroid supplementation increases it and thereby exerts neurotrophic effects via CREB activation.

Given the evidence for thyroid hormone involvement in mood disorders and their treatment, it is surprising that few functional imaging studies have examined these relationships. Marangell et al. ${ }^{209}$ reported an inverse relationship of peripheral TSH levels to brain activity. More recently, Bauer and colleagues ${ }^{210}$ used fluorodeoxyglucose PET to examine the effects of adjunctive supraphysiological doses of levothyroxine on cerebral glucose metabolism in euthyroid women with bipolar depression. Pretreatment scans of these women revealed abnormal glucose metabolism compared to healthy controls. After 7 weeks of levothyroxine treatment and significant clinical improvement, subsequent scans showed widespread metabolic decreases in limbic and subcortical areas including the amygdala, hippocampus, caudate, ventral striatum, thalamus, and cerebellar vermis, suggesting a link between the therapeutic effects of levothyroxine and modulation of regions implicated in key affective neuronal circuits.

\section{3) EXPERIMENTAL THERAPEUTICS TARGETING MEDIATORS OF CELLULAR RESILIENCE AND PLASTICITY}

We now turn to a discussion of several other plasticity-enhancing strategies currently under investigation in mood disorders (see FIG. 5 and Table 2 for an overview).

\section{The HPA axis as a target for the development of novel therapeutics}

Drugs that have been tested that modulate the HPA axis include inhibitors of glucocorticoid synthesis, glucocorticoid receptor (GR) antagonists (e.g., RU486), hydrocortisone to downregulate the HPA axis (as a proofof-concept study), CRH1 antagonists (e.g., antalarmin), and dehydroepiandrosterone (reviewed in Quiroz et al., $2004^{135}$ ). Examples are provided in Table 2. Some of these drugs are being investigated for proof of concept, and it is expected that modified and improved medica-

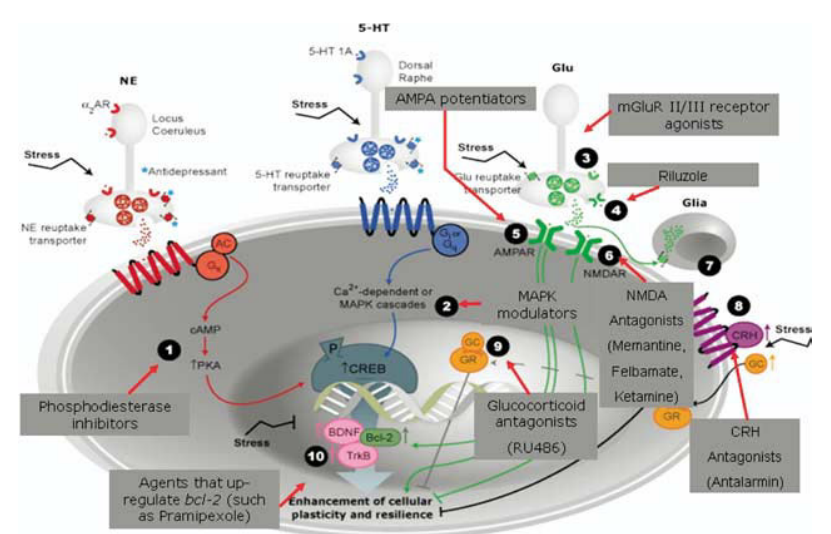

FIG. 5. Schematic depiction of putative sites of action for novel plasticity-enhancing medications in the treatment of mood disorders. NE $=$ norepinephrine; $\alpha 2 \mathrm{AR}=\alpha-2$ adrenoreceptor; $5-\mathrm{HT}$ = 5-hydroxytryptophan; Glu = glutamate; mGluR = metabotropic glutamate receptor; AMPAR = AMPA receptor; NMDAR = NMDA receptor; $\mathrm{CRH}=$ corticotropin-releasing hormone; $\mathrm{GC}=$ glucocorticoid; MAPK = MAP kinase; TrkB = tyrosine kinase receptor for BDNF; PKA = protein kinase $A$; $A C=$ adenyl cyclase. Modified from Charney and Manji 2004.

tions would lack some of the limiting side effects observed with these compounds.

\section{Glutamatergic strategies}

Because of the role of glutamate in neuronal plasticity, and independently of interactions with the HPA axis, modulation of the glutamatergic system is being investigated as a mood regulating strategy in a number of ongoing clinical studies by our group and others. ${ }^{211,212}$ Glutamate exerts its action at the presynaptic and postsynaptic level through the stimulation of specific ionotropic and metabotropic receptors (see FIG. 4). Therapeutics targeting these receptors and/or the presynaptic release of glutamate may result in modulation of the glutamatergic system and ultimately to circuitrysparing and mood-enhancing effects.

Inhibition of glutamate release. Efficacy of the anticonvulsant lamotrigine, ${ }^{213}$ now FDA-approved for the maintenance treatment of adults with $\mathrm{BD}$, provides clinical evidence that modulation of glutamatergic neurotransmission may be important in the treatment of mood disorders. ${ }^{214}$ Although lamotrigine has multiple cellular effects, inhibition of excessive presynaptic glutamate release appears to be important to its mechanism of action. ${ }^{215-217}$ Supporting this idea, there is now preliminary evidence that riluzole, another drug that inhibits the release of glutamate, also has antidepressant properties both in MDD and BD. ${ }^{218,219}$ Riluzole, approved by the FDA for the treatment of amyotrophic lateral sclerosis, exhibits neuroprotective properties in animal models of Parkinson's disease, NMDA receptor hypofunction neurotoxicity, ischemia and traumatic CNS injury. ${ }^{212,213}$

NMDA receptor antagonism. The NMDA receptor complex may be involved in the pathophysiology and 
treatment of mood disorders. NMDA receptor antagonists such as MK-801 and AP-7 have been shown to have antidepressant effects comparable to the tricyclic antidepressants in various animal models of depression. ${ }^{212}$ MK-801 increases neurogenesis in the brains of rats. ${ }^{220}$ A recently completed double-blind, placebo-controlled trial of the low- to moderate-affinity NMDA antagonist memantine in patients with MDD was negative. ${ }^{221}$ There is evidence that a single dose of the high-affinity NMDA receptor antagonist, ketamine, has efficacy in the treatment of depression. ${ }^{222,223}$ Studies in progress are examining the possible therapeutic value of other NMDA receptor antagonists.

AMPA receptors. AMPA receptors, a subfamily of ionotropic glutamate receptors that mediate the fast component of excitatory neurotransmission, are involved in learning and memory. Ampakines and several other classes of AMPA receptor potentiators (ARPs) allosterically modulate AMPA receptors to slow the rate of receptor desensitization and/or deactivation in the presence of an agonist (e.g., glutamate and AMPA). ${ }^{24,225}$ Various ARPs have demonstrated antidepressant properties in a number of preclinical models of depres$\operatorname{sion}^{226,227}$ (see Table 2). They have been associated with enhanced neurogenesis ${ }^{228}$ and increased expression of neurotrophic factors such as BDNF. ${ }^{229,230}$ The AMPAkine Ampalex exhibited more rapid effect (during the first week of treatment) than fluoxetine (after 2 weeks). ${ }^{231}$

Metabotropic glutamate receptors. In addition to the ionotropic receptors, G-protein-coupled metabotropic glutamate receptors (mGluR) mediate slower modulatory actions of glutamate on neurotransmitter release and cell excitability. Group I mGluR antagonists have potential therapeutic effects in CNS disorders involving excess excitatory neurotransmission (e.g., epilepsy and ischemia). ${ }^{232}$ Preclinical studies suggest that mGlu $2 / 3$ agonists have antianxiety, antipsychotic, and neuroprotective properties. ${ }^{233-235}$ Selective activation/antagonism of various mGluRs can lead to either anxiolytic- and/or antidepressant-like effects, ${ }^{236-239}$ and specific interactions of each receptor subtype are an intensive area of investigation. $^{212}$ The complex glutamate signaling system provides great potential for novel, plasticity-enhancing therapeutic strategies in mood disorders and other CNS disorders.

\section{Strategies to enhance neurotrophic factor signaling and neuroprotective effects}

One approach to enhance the activity of CREB is by inhibiting phosphodiesterase (PDE), the enzymes responsible for the breakdown of cAMP. Several previous studies have suggested that rolipram, a specific inhibitor of the high-affinity cAMP PDE4, may have antidepressant efficacy in depressed patients. ${ }^{134}$ Although studies of rolipram have not been pursued further due to doselimiting side effects, these data suggest that PDE4A and PDE4B may be worthwhile targets for development of novel antidepressant agents, either as monotherapy or in conjunction with agents that augment intrasynaptic monoamine levels due to potential synergistic effects on the cAMP cascade.

Multiple strategies are being investigated to develop agents to regulate the activity of growth factors, MAP kinase cascades, and the Bcl-2 family of proteins (see FIG. 3 and Table 2). The neuroprotective Bcl-2 is a key regulator of mitochondrial function, and there is a growing appreciation of the critical functions of mitochondria in regulating integrated CNS function. For example, increasing evidence suggests that mitochondrial $\mathrm{Ca}^{2+}$ sequestration plays a key role in modulating the tone of synaptic plasticity in a variety of neuronal circuits. Lithium's ability to robustly upregulate Bcl-2 may is likely involved in its antidepressant potentiating effects. Pramipexole, shown to exert antidepressant effects in a double-blind placebo-controlled trial in patients with bipolar II depression, ${ }^{110}$ upregulates Bcl-2 in several brain regions. Although the dopamine agonistic effects of pramipexole may also contribute to its antidepressant effects, its neurotrophic effects suggest broader utility as an antidepressant potentiator.

\section{CONCLUSIONS}

Despite currently available treatments, MDD and BD remain leading causes of disability worldwide, illustrating the need for novel therapeutic strategies in addressing these illnesses.

Through functional brain imaging studies, affective circuits have been identified that mediate the behavioral, cognitive, and somatic manifestations of mood disorders. Key areas of these circuits include the amygdala and related limbic structures, orbital and medial prefrontal cortex, anterior cingulate, medial thalamus, and related regions of the basal ganglia. Imbalance within these circuits, rather than an increase or decrease in any single region of the circuit, seems to predispose to and mediate the expression of affective illness.

Factors that impact neuroplasticity and cellular resilience, such as altered HPA axis and glutamate neurotransmission and impaired neurotrophic/neuroprotective signaling, appear to underlie disturbances in these key affective circuits. Treatments that more directly restore balance to these circuits may prove more effective in those with mood disorders, particularly in refractory cases. Promising experimental approaches include pharmacological restoration of these circuits using neuroplasticity-enhancing strategies such as modulation of altered HPA axis or glutamatergic activity and manipulation of key neurotrophic/neuroprotective signaling cascades 
and, possibly, direct stimulation of these circuits via instrumentation (e.g., deep brain stimulation, magnetic stimulation, or vagus nerve stimulation). As these novel treatment strategies are developed further, functional imaging studies of these interventions (including molecular imaging techniques as well as circuit-based approaches) are likely to yield greater understanding into the mechanisms of response for these treatments and the underlying neurobiology of mood disorders, leading ultimately to more refined and specifically targeted therapies.

Acknowledgments: We would like to acknowledge the support of the Intramural Research Program of the National Institute of Mental Heath, the Stanley Medical Research Institute and NARSAD. Due to space limitations, we often cited review papers and apologize to those authors whose original data could not be included. None of the investigators in this study have a possible conflict of interest, financial or otherwise.

\section{REFERENCES}

1. World Health Organization. Chapter 2. Burden of Mental and Behavioral Disorders. In the WHO Report 2001: Mental Health, New Understandings, New Hope. http://www.who.int/whr/2001/ en/whr01_ch2_en.pdf. 19-34, 2001.

2. Fagiolini A, Kupfer DJ, Masalehdan A, Scott JA, Houck PR, Frank E. Functional impairment in the remission phase of bipolar disorder. Bipolar Disord 7:281-285, 2005.

3. Murray CJ, Lopez AD. Global mortality, disability, and the contribution of risk factors: Global Burden of Disease Study. Lancet 349:1436-1442, 1997.

4. Revicki DA, Matza LS, Flood E, Lloyd A. Bipolar disorder and health-related quality of life: review of burden of disease and clinical trials. Pharmacoeconomics 23:583-594, 2005.

5. Tohen M, Zarate ZA Jr, Hennen J, et al. The McLean-Harvard First-Episode Mania Study: prediction of recovery and first recurrence. Am J Psychiatry 160:2099-2107, 2003.

6. Ciechanowski PS, Katon WJ, Russo JE. Depression and diabetes: impact of depressive symptoms on adherence, function, and costs. Arch Intern Med 160:3278-3285, 2000.

7. Kupfer D. The increasing medical burden in bipolar disorder. JAMA 293:2528-2530, 2005.

8. Michelson D, Stratakis C, Hill L, et al. Bone mineral density in women with depression. $N$ Engl J Med 335:1176-1181, 1996.

9. Musselman DL, Evans DL, Nemeroff CB. The relationship of depression to cardiovascular disease: epidemiology, biology, and treatment. Arch Gen Psychiatry 55:580-592, 1998.

10. Drevets W. Neuroimaging and neuropathological studies of depression: implications for the cognitive-emotional features of mood disorders. Curr Opin Neurobiol 11:240-249, 2001.

11. Nestler EJ, Barrot M, DiLeone RJ, Eisch AJ, Gold SJ, Monteggia LM. Neurobiology of depression. Neuron 34:13-25, 2002.

12. Drevets WC. Neuroimaging studies of mood disorders. Biol Psychiatry 48:813-829, 2000.

13. Blasi G, Bertolino A. Imaging genomics and response to treatment with antipsychotics in schizophrenia. NeuroRx 3:117-130, 2006.

14. Winokur G. The development and validity of familial subtypes in primary unipolar depression. Pharmacopsychiatry 15:142-146, 1982.

15. Drevets WC, Price JL, Bardgett ME, Reich T, Todd RD, Raichle ME. Glucose metabolism in the amygdala in depression: relationship to diagnostic subtype and plasma cortisol levels. Pharmacol Biochem Behav 71:431-447, 2002.

16. Drevets WC, Spitznagel E, Raichle ME. Functional anatomical differences between major depressive subtypes. J Cereb Blood Flow Metab 15:S93, 1995.
17. Drevets WC, Videen TO, Price JL, Preskorn SH, Carmichael ST, Raichle ME. A functional anatomical study of unipolar depression. J Neurosci 12:3628-3641, 1992.

18. Wu J, Gillin JC, Buchsbaum MS, Hershey T, Johnson JC, Bunney WE Jr. Effect of sleep deprivation on brain metabolism of depressed patients. Am J Psychiatry 149:538-543, 1992.

19. Drevets WC, Botteron K. Neuroimaging in psychiatry. In: Adult psychiatry (Guze SB, ed), pp 53-81. St. Louis: Mosby, 1997.

20. Abercrombie HC, Larson CL, Ward RT, Schaefer SM, Holden JE, Perlman SB, et al. Metabolic rate in the amygdala predicts negative affect and depression severity in depressed patients: an FDG-PET study. Neuroimage 3:S217, 1996.

21. Bremner JD, Innis RB, Salomon RM, Staib LH, Ng CK, Miller $\mathrm{HL}$, et al. Positron emission tomography measurement of cerebral metabolic correlates of tryptophan depletion-induced dperessive relapse. Arch Gen Psychiatry 54:346-374, 1997.

22. Anand A, Li Y, Wang Y, Wu J, Gao S, Bukhari L, Mathews VP, Kalnin A, Lowe MJ. Activity and connectivity of brain mood regulating circuit in depression: a functional magnetic resonance study. Biol Psychiatry 57:1079-1088, 2005.

23. Haldane M, Frangou S. New insights help define the pathophysiology of bipolar affective disorder: neuroimaging and neuropathology findings. Prog Neuropsychopharm Biol Psychiatry 28: 943-960, 2004.

24. Surguladze S, Brammer MJ, Keedwell P, Giampietro V, Young AW, Travis MJ, Williams SC, Phillips ML. A differential pattern of neural response toward sad versus happy facial expressions in major depressive disorder. Biol Psychiatry 57:201-209, 2005.

25. Hariri AR, Drabant EM, Munoz KE, Kolachana BS, Mattay VS, Egan MF, Weinberger DR. A susceptibility gene for affective disorders and the response of the human amygdala. Arch Gen Psychiatry 62:146-152, 2005.

26. Heinz A, Braus DF, Smolka MN, Wrase J, Puls I, Hermann D, Klein S, Grusser SM, Flor H, Schumann G, Mann K, Buchel C. Amygdala-prefrontal coupling depends on a genetic variation of the serotonin transporter. Nat Neurosci 8:20-21, 2005.

27. Pezawas L, Meyer-Lindenberg A, Drabant EM, Verchinski BA, Munoz KE, Kolachana BS, Egan MF, Mattay VS, Hariri AR, Weinberger DR. 5-HTTLPR polymorphism impacts human cingulate-amygdala interactions: a genetic susceptibility mechanism for depression. Nat Neurosci 8:828-834, 2005.

28. Everitt BJ, Parkinson JA, Olmstead MC, Arroyo M, Robledo P, Robbins TW. Associative processes in addiction and reward. The role of amygdala-ventral striatum subsystems. Ann NY Acad Sci 877:412-438, 1999.

29. Cahill L, Weinberger NM, Roozendaal B, McGaugh JL. Is the amygdala a locus of "conditioned fear"? Some questions and caveats. Neuron 23:227-228, 1999.

30. Davis M. Are different parts of the extended amygdala involved in fear versus anxiety? Biol Psychiatry 44:1239-1247, 1998.

31. Ledoux J. Emotion circuits in the brain. Annu Rev Neurosci 23:155-184, 2000.

32. Baxter LR, Phelps ME, Mazziotta JC, Guze BH, Schwartz JM, Selin CE. Local cerebral glucose metabolic rates in obsessivecompulsive disorder-a comparison with rates in unipolar depression and in normal controls. Arch Gen Psychiatry 44:211218, 1987.

33. Biver F, Goldman S, Delvenne V, Luxen A, DeMaertelaer V, Hubain $\mathrm{P}$, et al. Frontal and parietal metabolic disturbances in unipolar depression. Biol Psychiatry 36:381-388, 1994.

34. Cohen RM, Gross M, Nordahl TE, Semple WE, Oren DA, Rosenthal N. Preliminary data on the metabolic brain pattern of patients with winter seasonal affective disorder. Arch Gen Psychiatry 49:545-552, 1992.

35. Ebert D, Feistel H, Barocka A. Effects of sleep deprivation on the limbic system and the frontal lobes in affective disorders: a study with Tc-99m-HMPAO SPECT. Psychiatry Res 40:247-251, 1991.

36. Drevets WC, Raichle ME. Reciprocal suppression of regional cerebral blood flow during emotional versus higher cognitive processes: implications for interactions between emotion and cognition. Cogn Emotion 12:353-385, 1998. 
37. Brody AL, Saxena S, Silverman DHS, Alborzian S, Fairbanks LA, Phelps ME, et al. Brain metabolic changes in major depressive disorder from pre- to post-treatment with paroxetine. Psychiatry Res Neuroimaging 91:127-139, 1999.

38. Mayberg HS, Liotti M, Brannan SK, McGinnis BS, Mahurin RK, Jerabek PA, et al. Reciprocal limbic-cortical function and negative mood: converging PET findings in depression and normal sadness. Am J Psychiatry 156:675-682, 1999.

39. Nobler MS, Sackeim HA, Prohovnik I, Moeller JR, Mukherjee S, Schnur DB, et al. Regional cerebral BF in mood disorders, III. Treatment and clinical response. Arch Gen Psychiatry 51:884897, 1994.

40. Carmichael ST, Price JL. Limbic connections of the orbital and medial prefrontal cortex in Macaque monkeys. J Comp Neurol 363:615-641, 1995.

41. Mogenson GJ, Brudzynski SM, Wu M, Yang CR, Yim CCY. From motivation to action: a review of dopaminergic regulation of limbic-nucleus accumbens-ventral pallidum-pediculopontine nucleus circuitries involved in limbic-motor integration. In: Limbic motor circuits and neuropsychiatry (Kalivas PW, Barnes CD, eds), pp 193-236. London: CRC Press, 1993.

42. Price JL. Networks within the orbital and medial prefrontal cortex. Neurocase 5:231-241, 1999.

43. Price JL, Carmichael ST, Drevets WC. Networks related to the orbital and medial prefrontal cortex; a substrate for emotional behavior? In: Progress in brain research: the emotional motor system (Holstege G, Bandler R, Saper CB, eds) 107:523-536. Amsterdam: Elsevier, 1996.

44. Rolls E. A theory of emotion and consciousness and its application to understanding the neural basis of emotion. In: The cognitive neurosciences (Gazzaniga MS, ed), pp 1091-1106. Cambridge: MIT Press, 1995.

45. Sullivan RM, Gratton A. Lateralized effects of medial prefrontal cortex lesions on neuroendocrine and autonomic stress responses in rats. J Neurosci 19:2834-2840, 1999.

46. Bechara A, Dasmasio H, Tranel D, Anderson SW. Dissociation of working memory from decision-making within the human prefrontal cortex. J Neurosci 18:428-437, 1998.

47. Elliott R, Dolan RJ, Frith CD. Dissociable functions in the medial and lateral orbitofrontal cortex: evidence from human neuroimaging studies. Cereb Cortex 10:308-317, 2000.

48. Iversen SD, Mishkin M. Perseverative interference in monkeys following selective lesions of the inferior prefrontal convexity. Exp Brain Res 11:376-386, 1970.

49. Sortres-Bayon F, Bush DE, LeDoux JE. Emotional perseveration: an update on prefrontal-amygdala interactions in fear extinction. Learn Mem 11:525-535, 2004.

50. Buchsbaum MS, Wu J, Siegel BV, Hackett E, Trenary M, Abel L, Reynolds C. Effect of sertraline on regional metabolic rate in patients with affective disorder. Biol Psychiatry 41:15-22, 1997.

51. Drevets WC, Price JL, Simpson JR, Todd RD, Reich T, Vannier M, Raichle ME. Subgenual prefrontal cortex abnormalities in mood disorders. Nature 386:824-827, 1997.

52. Kegeles LS, Malone KM, Slifstein M, Anjilvel S, Xanthopoulos C, Campell M, et al. Response of cortical metabolic deficits to serotonergic challenges in mood disorders. Biol Psychiatry 45: 76S, 1999

53. Hirayasu Y, Shenton ME, Salisbury DF, Kwon JS, Wible CG, Fischer LA, et al. Subgenual cingulate cortex volume in first episode psychosis. Am J Psychiatry 156:1091-1093, 1999.

54. Drevets WC, Gadde KM, Krishnan R. Neuroimaging studies of depression. In: Neurobiology of mental illness (Charney DS, Nestler EJ, Bunney BJ, eds), pp 394-418. New York: Oxford University Press, 1999.

55. Drevets WC. Functional anatomical abnormalities in limbic and prefrontal cortical structures in major depression. Prog Brain Res 126:413-431, 2000.

56. Drevets WC, Videen TO, Snyder AZ, MacLeod AK, Raichle ME. Regional cerebral blood flow changes during anticipatory anxiety. Abstr Soc Neurosci 20:368, 1994.

57. Frysztak RJ, Neafsey EJ. The effect of medial frontal cortex lesions on cardiovascular conditioned emotional responses in the rat. Brain Res 643:181-193, 1994.
58. Baxter LR, Schwartz JM, Phelps ME, Mazziotta JC, Guze BH, Selin CE, et al. Reduction of prefrontal cortex glucose metabolism common to three types of depression. Arch Gen Psychiatry 46:243-250, 1989.

59. Drevets WC. Prefrontal cortical-amygdalar metabolism in major depression. Ann NY Acad Sci 877:614-637, 1999.

60. Ring HA, Bench CJ, Trimble MR, Brooks DJ, Frackowiak RSJ, Dolan RJ. Depression in Parkinson's disease: a positron emission study. Br J Psychiatry 165:333-339, 1994.

61. Goethals I, Audenaert K, Jacobs F, Van de Wiele C, Ham H, Pyck $\mathrm{H}$, Vandierendonck A, Van Heeringen C, Dierckx R. Blunted prefrontal perfusion in depressed patients performing the Tower of London task. Psychiatry Res 139:31-40, 2005.

62. Bench CJ, Frackowiak RS, Dolan RJ. Changes in regional cerebral blood flow on recovery from depression. Psychol Med 25: 247-251, 1995.

63. Apud JA. The pharmocogenomics of the dorsolateral prefrontal cortex: a new tool for the development of "target-oriented" $\operatorname{cog}$ nitive enhancing drugs. NeuroRx 3:106-116, 2006.

64. Hooley JM, Gruber SA, Scott LA, Hiller JB, Yurgelun-Todd DA Activation in dorsolateral prefrontal cortex in response to maternal criticism and praise in recovered depressed and healthy control participants. Biol Psychiatry 57:809-812, 2005.

65. Carlson PJ, Thase M, Bogers W, Kupfer DJ, Drevets WC. Medial thalamic metabolism is increased in depression, and decreases with treatment. Neuroimage 26:S28, 2005.

66. Drevets W. PET and the functional anatomy of major depression. In: Emotion, memory and behavior-study of human and nonhuman primates (Nakajima T, Ono T, eds), pp 43-62. Tokyo: Japan Scientific Societies Press, 1995.

67. Germain A, Nofzinger EA, Kupfer DJ, Buysse DJ. Neurobiology of non-REM sleep in depression: further evidence for hypofrontality and thalamic dysregulation. Am J Psychiatry 161:18561863, 2004.

68. Keedwell PA, Andrew C, Williams SCR, Brammer MJ, Phillips ML. The neural correlates of anhedonia in major depressive disorder. Biol Psychiatry 58:843-853, 2005.

69. Blumberg HP, Stern E, Martinez D, Ricketts S, de Asis J, White $\mathrm{T}$, et al. Increased anterior cingulate and caudate activity in bipolar mania. Biol Psychiatry 48:1045-1052, 2000.

70. Davidson RJ, Irwin W, Anderle MJ, Kalin NH. The neural substrates of affective processing in depressed patients treated with venlafaxine. Am J Psychiatry 160:64-75, 2003.

71. Brambilla P, Nicoletti M, Harenski K, Sassi RB, Mallinger AG, Frank E, et al. Anatomical MRI study of subgenual prefrontal cortex in bipolar and unipolar subjects. Neuropsychopharmacology 27:792-799, 2002.

72. Bremner JD, Vythilingam M, Vermetten E, Nazeer A, Adil J, Khan S, et al. Reduced volume of orbitofrontal cortex in major depression. Biol Psychiatry 51:273-279, 2002.

73. Fossati P, Radtchenko A, Boyer P. Neuroplasticity: from MRI to depressive symptoms. Eur Neuropsychopharmacol 14:S503S510, 2004.

74. Kanner A. Structural MRI changes of the brain in depression. Clin EEG Neurosci 35:46-52, 2004.

75. Lacerda ALT, Keshavan MS, Hardan AY, Yorbik O, Brambilla P, Sassi RB, Nicoletti M, Mallinger AG, Frank E, Kupfer DJ, Soares JC. Anatomic evaluation of the orbitofrontal cortex in major depressive disorder. Biol Psychiatry 55:353-358, 2004.

76. Dickstein DP, Milham MP, Nugent AC, Drevets WC, Charney DS, Pine DS, Leibenluft E. Frontotemporal alterations in pediatric bipolar disorder. Arch Gen Psychiatry 62:734-741, 2005.

77. Rosso IM, Cintron CM, Steingard RJ, Renshaw PF, Young AD, Yurgelun-Todd DA. Amygdala and hippocampus volumes in pediatric major depression. Biol Psychiatry 57:21-26, 2005.

78. Cotter D, Mackay D, Landau S, Kerwin R, Everall I. Reduced glial cell density and neuronal size in the anterior cingulate cortex in major depressive disorder. Arch Gen Psychiatry 58:545-553, 2001.

79. Manji HK, Duman RS. Impairments of neuroplasticity and cellular resilience in severe mood disorder: implications for the development of novel therapeutics. Psychopharmacol Bull 35:549, 2001. 
80. Rajkowska G. Cell pathology in bipolar disorder. Bipolar Disord 4:105-116, 2002.

81. Coyle JT, Schwarcz R. Mind glue: implications of glial cell biology for psychiatry. Arch Gen Psychiatry 57:90-93, 2000.

82. Haydon P. GLIA: listening and talking to the synapse. Nat Rev Neurosci 2:185-193, 2001.

83. Ongur D, Drevets WC, Price JL. Glial reduction in the subgenual prefrontal cortex in mood disorders. Proc Natl Acad Sci USA 95:13290-13295, 1998.

84. Rajkowska G. Postmortem studies in mood disorders indicate altered numbers of neurons and glial cells. Biol Psychiatry 48: 756-777, 2000.

85. Rajkowska G, Miguel-Hidalgo JJ, Wei J, Dilley G, Pittman SD, Meltzer HY, Overholser JC, Roth BL, Stockmeier CA. Morphometric evidence for neuronal and glial prefrontal cell pathology in major depression. Biol Psychiatry 45:1085-1098, 1999.

86. Ullian EM, Sapperstein SK, Christopherson KS, Barres BA. Control of synapse number by glia. Science 291:657-661, 2001.

87. Price JL. Comparative aspects of amygdala connectivity. Ann NY Acad Sci 985:50-58, 2003.

88. Blumberg HP, Kaufman J, Martin A, Charney DS, Krystal JH, Peterson BS. Significance of adolescent neurodevelopment for the neural circuitry of bipolar disorder. Ann NY Acad Sci 1021: 376-383, 2004.

89. Blumberg HP, Martin A, Kaufman J, Leung HC, Skudlarski P, Lacadie CM, et al. Frontostriatal abnormalities in adolescents with bipolar disorder: preliminary observations from function MRI. Am J Psychiatry 160:1345-1347, 2003.

90. Canli T, Sivers H, Thomason ME, Whitfiiled-Gabrieli S, Gabrieli $\mathrm{JD}$, Gotlib IH. Brain activation to emotional words in depressed vs. healthy subjects. Neuroreport 15:2585-2588, 2004.

91. Chen CH, Lennox B, Jacob R, Calder A, Lupson V, BisbrownChippendale R, Suckling J, Bullmore E. Explicit and implicit facial affect recognition in manic and depressed states of bipolar disorder: a functional magnetic resonance imaging study. Biol Psychiatry 59:31-39, 2006.

92. Irwin W, Anderele MJ, Abercrombie HC, Schaefer SM, Kalin $\mathrm{NH}$, Davidson RJ. Amygdalar interhemispheric functional connectivity differs between the non-depressed and depressed human brain. Neuroimage 21:674-686, 2004.

93. Kumari V, Mitterschiffthaler MT, Teasdale JD, Malhi GS, Brown RG, Giampietro V, Brammer MJ, Poon L, Simmons A, Williams SC, Checkley SA, Sharma T. Neural abnormalities during cognitive generation of affect in treatment-resistant depression. Biol Psychiatry 54:777-791, 2003.

94. Lawrence NS, Williams AM, Surguladze S, Giampietro V, Brammer MJ, Andrew C, Frangou S, Ecker C, Phillips ML. Subcortical and ventral prefrontal cortical neural responses to facial expressions distinguish patients with bipolar disorder and major depression. Biol Psychiatry 55:578-587, 2004.

95. Malhi GS, Lagopoulos J, Ward PB, Kumari V, Mitchell PB, Parker GB, Ivanovski B, Sachdev P. Cognitive generation of affect in bipolar depression: an fMRI study. Eur J Neurosci 19:741-754, 2004.

96. Milak MS, Parsey RV, Keilp J, Oquendo MA, Malone KM, Mann JJ. Neuroanatomic correlates of psychopathologic components of major depressive disorder. Arch Gen Psychiatry 62:397-408, 2005.

97. Folstein SE, Peyser CE, Starkstein SE, Folstein MF. Subcortical triad of Huntington's disease-a model for a neuropathology of depression, dementia, and dyskinesia. In: Psychopathology and the brain (Carrol BJ, Barrett JE, eds), pp 65-75. New York: Raven Press, 1991.

98. Mayeux R. Depression and dementia in Parkinson's disease. In: Movement disorders (Marsden CO, Fahn S, eds), pp 75-95. London: Butterworth, 1982.

99. Starkstein SE, Robinson RG. Affective disorders and cerebral vascular disease. Br J Psychiatry 174:170-182, 1989.

100. Ballantine HT, Bouckoms AJ, Thomas EK, Giriunas IE. Treatment of psychiatric illness by stereotactic cingulotomy. Biol Psychiatry 22:807-819, 1987.

101. Corsellis J, Jack AB. Neuropathological observations on yttrium implants and on undercutting in the orbito-frontal areas of the brain. In: Surgical approaches in psychiatry (Laitinen LV, Livingston KE, eds), pp 90-95. Lancaster, England: Medical \& Technical Publishing Co., 1973.

102. Knight G. Stereotactic tractotomy in the surgical treatment of mental illness. J Neurol Neurosurg Psychiatry 28:30, 1965.

103. Nauta WJH, Domesick V. Afferent and efferent relationships of the basal ganglia. In: Function of the basal ganglia, CIBA Foundation Symposium (Evered D, O'Connor M eds) 107:3-29, 1984.

104. Newcombe R. The lesion in stereotactic subcaudate tractotomy. Br J Psychiatry 126:478, 1975.

105. Nicolaidis S. Depression and neurosurgery: past, present, and future. Metab Clin Exp 54:28-32, 2005.

106. Velasco F, Velasco M, Jimenez F, Velasco AL, Salin-Pascual R. Neurobiological background for performing surgical intervention in the inferior thalamic peduncle for treatment of major depression disorders. Neurosurgery 57:439-448, 2005.

107. Anand A, Li Y, Wang Y, Wu J, Gao S, Bukhari L, Mathews VP, Kalnin A, Lowe MJ. Antidepressant effect on connectivity of the mood-regulating circuit: an fMRI study. Neuropsychopharmacology 30:1334-1344, 2005.

108. Fu CH, Williams SC, Cleare AJ, Brammer MJ, Walsh ND, Kim J, Andrew CM, Pich EM, Williams PM, Reed LJ, Mitterschiffthaler MT, Suckling J, Bullmore ET. Attenuation of the neural response to sad faces in major depression by antidepressant treatment: a prospective, event-related functional magnetic resonance imaging study. Arch Gen Psychiatry 61:877-889, 2004.

109. Little JT, Ketter TA, Kimbrell TA, Dunn RT, Benson BE, Willis MW, Luckenbaugh DA, Post RM. Bupropion and venlafaxine responders differ in pretreatment regional cerebral metabolism in unipolar depression. Biol Psychiatry 57:220-228, 2005.

110. Zarate CA Jr, Quiroz JA, Singh JB, Quiroz JA, Luckenbaugh DA, Denicoff KD, Charney DS, Manji HK. Pramipexole for bipolar II depression: a placebo-controlled proof of concept study. Biol Psychiatry 56:54-60, 2004.

111. Goldberg JF, Burdick KE, Endick CJ. Preliminary randomized, double-blind, placebo-controlled trial of pramipexole added to mood stabilizers for treatment-resistant bipolar depression. Am J Psychiatry 161:564-566, 2004.

112. Zarate CA Jr. Cerebral metabolic changes in bipolar depressed patients treated with the D2/D3 receptor agonist pramipexole. Program of the 6th International Conference on Bipolar Disorders, Pittsburgh, PA, 2005.

113. Sackeim HA, Prudic J, Devanand DP, et al. Effects of stimulus intensity and electrode placement on the efficacy and cognitive effects of electroconvulsive therapy. N Engl J Med 328:839-846, 1993.

114. Nobler MS, Oquendo MA, Kegeles LS, et al. Decreased regional brain metabolism after ECT. Am J Psychiatry 158:305-308, 2001.

115. Brody AL, Saxena S, Stoessel P, Gillies LA, Fairbanks LA, Alborzian S, Phelps ME, Huang SC, Wu HM, Ho ML, Ho MK, Au SC, Maidment K, Baxter LR. Regional brain metabolic changes in patients with major depression treated with either paroxetine or interpersonal therapy: preliminary findings. Arch Gen Psychiatry 58:631-640, 2001.

116. Goldapple K, Segal Z, Garson C, Lau M, Bieling P, Kennedy S, Mayberg H. Modulation of cortical-limbic pathways in major depression. Arch Gen Psychiatry 61:34-41, 2004.

117. Lisanby SH, Luber B, Schlaepfer TE, Sackeim HA. Safety and feasibility of magnetic seizure therapy (MST) in major depression: randomized within-subject comparison with electroconvulsive therapy. Neuropsychopharmacology 28:1852-1865, 2003.

118. George MS, Nahas Z, Li X, Kozel FA, Anderson B, Yamanaka K, Chae JH, Foust MJ. Novel treatment of mood disorders based on brain circuitry (ECT, MST, TMS, VNS, DBS). Semin Clin Neuropsychiatry 7:293-304, 2002.

119. Avery DH, Holtzheimer PE, Fawaz W, Russo J, Neumaier J, Dunner DL, Haynor DR, Claypoole KH, Wajdik C, Roy-Byrne P. A controlled study of repetitive transcranial magnetic stimulation in medication-resistant major depression. Biol Psychiatry, in press.

120. Sapolsky R. Is impaired neurogenesis relevant to the affective symptoms of depression? Biol Psychiatry 56:137-139, 2004. 
121. Chae JH, Nahas Z, Lomarev M, Denslow S, Lorberbaum JP, Bohning DE, George MS. A review of functional neuroimaging studies of vagus nerve stimulation (VNS). J Psychiatr Res 37: 443-455, 2003.

122. Narayanan JT, Watts R, Haddad N, Labar DR, Mark Li P, Filippi CG. Cerebral activation during vagus nerve stimulation: a functional MR study. Epilepsia 43:1509-1514, 2002.

123. Rush A, George MS, Sackeim HA, Marangell LB, Husain M, Nahas Z, et al. Continuing benefit of VNS therapy over 2 years for treatment-resistant depression. Poster presented at the 43rd Annual NCDEU Meeting, 2003.

124. Sackheim HA, Rush AJ, George MS, et al. Vagus nerve stimulation (VNS) for treatment-resistant depression: efficacy, side effects, and predictors of outcome. Neuropsychopharmacology 25:713-728, 2001.

125. Rush AJ, Marangell LB, Sackeim HA, George MS, Brannan SK, Davis SM, Howland R, Kling MA, Rittberg BR, Burke WJ, Rapaport MH, Zajecka J, Nierenberg AA, Husain MM, Ginsberg D, Cooke RG. Vagus nerve stimulation for treatment-resistant depression: a randomized, controlled acute phase trial. Biol Psychiatry 58:347-354, 2005.

126. George MS, Rush AJ, Marangell LB, Sackeim HA, Brannan SK, Davis SM, Howland R, Kling MA, Moreno F, Rittberg B, Dunner D, Schwartz T, Carpenter L, Burke M, Ninan P, Goodnick P. A one-year comparison of vagus nerve stimulation with treatment as usual for treatment-resistant depression. Biol Psychiatry 58:364373, 2005.

127. Rush AJ, Sackeim HA, Marangell LB, George MS, Brannan SK, Davis SM, Lavori P, Howland R, Kling MA, Rittberg B, Carpenter L, Ninan P, Moreno F, Schwartz T, Conway C, Burke M, Barry JJ. Effects of 12 months of vagus nerve stimulation in treatment-resistant depression: a naturalistic study. Biol Psychiatry 58:355-363, 2005.

128. Benabid A. Deep brain stimulation for Parkinson's disease. Curr Opin Neurobiol 13:696-706, 2003.

129. Lang AE, Lozano AM. Parkinson's disease. Second of two parts. N Engl J Med 339:1130-1143, 1998.

130. Mayberg HS, Lozano AM, Voon V, McNeely HE, Seminowicz D, Hamani C, Schwalb JM, Kennedy SH. Deep brain stimulation for treatment-resistant depression. Neuron 45:651-660, 2005.

131. McIntyre CC, Savasta M, Walter BL, Vitek JL. How does deep brain stimulation work? Present understanding and future questions. J Clin Neurophysiol 21:40-50, 2004.

132. Jimenez F, Velasco F, Salin-Pascual R, Hernandez JA, Velasco M, Criales JL, Nicolini H. A patient with a resistant major depression disorder treated with deep brain stimulation in the inferior thalamic peduncle. Neurosurgery 57:585-593, 2005.

133. D'Sa C, Duman RS. Antidepressants and neuroplasticity. Bipolar Disord 4:183-194, 2002.

134. Manji HK, Quiroz JA, Sporn J, Payne JL, Denicoff KD, Gray N, Zarate CA, Charney DS. Enhancing neuronal plasticity and cellular resilience to develop novel, improved therapeutics for dificult to treat depression. Biol Psychiatry 53:707-742, 2003.

135. Quiroz JA, Singh J, Gould TD, Denicoff KD, Zarate CA, Manji HK. Emerging experimental therapeutics for bipolar disorder: clues from the molecular pathophysiology. Mol Psychiatry 9:756-776, 2004.

136. Young L. Neuroprotective effects of antidepressant and mood stabilizing drugs. J Psychiatry Neurosci 27:8-9, 2002.

137. Holzheimer PE III, Nemeroff CB. Advances in the treatment of depression. NeuroRx 3:42-56, 2006.

138. Brown ES, Rush AJ, McEwen BS. Hippocampal remodeling and damage by corticosteroids: implications for mood disorders. Neuropsychopharmacology 21:474-484, 1999.

139. McEwen B. Stress and hippocampal plasticity. Annu Rev Neurosci 22:105-122, 1999.

140. Sapolsky R. Glucocorticoids and hippocampal atrophy in neuropsychiatric disorders. Arch Gen Psychiatry 57:925-935, 2000.

141. Watson S, Gallagher P, Ritchie JC, Ferrier IN, Young AH. Hypothalamic-pituitary-adrenal axis functions in patients with bipolar disorder. Br J Psychiatry 184:496-502, 2004.

142. Brown SM, Henning S, Wellman CL. Mild, Short-term stress alters dendritic morphology in rat medial prefrontal cortex. Cereb Cortex 15:1714-1722, 2005.

143. Cook SC, Wellman CL. Chronic stress alters dendritic morphology in rat medial prefrontal cortex. J Neurobiol 60:236-248, 2004.

144. Wellman CL. Dendritic reorganization in pyramidal neurons in medial prefrontal cortex after chronic corticosterone administration. J Neurobiol 49:245-253, 2001.

145. McEwen BS, Reagan LP. Glucose transporter expression in the central nervous system: relationship to synaptic function. Eur J Pharmacol 490:13-24, 2004.

146. Magistretti PJ, Pellerin L, Martin JL. Brain energy metabolism: an integrated cellular perspective. In: Psychopharmacology: the fourth generation of progress (Bloom FE, Kupfer DJ, eds), pp 921-932. New York: Raven Press, 1995.

147. Kato T, Kato N. Mitochondrial dysfunction in bipolar disorder. Bipolar Disord 2:180-190, 2000.

148. Stork C, Renshaw PF. Mitochondrial dysfunction in bipolar disorder: evidence from magnetic resonance spectroscopy research. Mol Psychiatry 10:900-919, 2005.

149. Kato T. Mitochondrial dysfunction in bipolar disorder: from 31Pmagnetic resonance spectroscopic findings to their molecular mechanisms. Int Rev Neurobiol 63:21-40, 2005.

150. Szabo ST, Gould TD, Manji HK. Introduction to neurotransmitters, receptors, signal transduction, and second messengers. In: Textbook of psychopharmacology (Nemeroff CB, Schatzberg AF, eds), Ed 3. Arlington, VA: The American Psychiatric Publishing, 2003.

151. Bowden CL, Huang LG, Javors MA, Johnson JM, Seleshi E, McIntyre K, et al. Calcium function in affective disorders and healthy controls. Biol Psychiatry 23:367-376, 1988.

152. Konradi C, Eaton M, MacDonald ML, Walsh J, Benes FM, Heckers S. Molecular evidence for mitochondrial dysfunction in bipolar disorder. Arch Gen Psychiatry 61:300-308, 2004.

153. Patapoutian A, Reichardt LF. Trk receptors: mediators of neurotrophin action. Curr Opin Neurobiol 11:272-280, 2001.

154. Blum R, Konnerth A. Neurotrophin-mediated rapid signaling in the central nervous system: mechanisms and functions. Physiology (Bethesda) 20:70-78, 2005.

155. Lu B, Pang PT, Woo NH. The yin and yang of neurotrophin action. Nat Rev Neurosci 6:603-614, 2005.

156. Egan MF, Kojima M, Callicott JH, Goldberg TE, Kolachana BS, Bertolino A, et al. The BDNF val66met polymorphism affects activity-dependent secretion of BDNF and human memory and hippocampal function. Cell 112:257-269, 2003.

157. Almeida RD, Manadas BJ, Melo CV, Gomes JR, Mendes CS, Graos MM, et al. Neuroprotection by BDNF against glutamateinduced apoptotic cell death is mediated by ERK and PI3-kinase pathways. Cell Death Differ 12:1329-1343, 2005.

158. Levine ES, Crozier RA, Black IB, Plummer MR. Brain-derived neurotrophic factor modulates hippocampal synaptic transmission by increasing N-methyl-D-aspartic acid receptor activity. Proc Natl Acad Sci USA 95:10235-10239, 1998.

159. DeVries AC, Joh HD, Bernard O, Hattori K, Hurn PD, Traystman RJ, et al. Social stress exacerbates stroke outcome by suppressing Bcl-2 expression. Proc Natl Acad Sci USA 98:11824-11828, 2001.

160. Duman RS, Malberg J, Thome J. Neural plasticity to stress and antidepressant treatment. Biol Psychiatry 46:1181-1191, 1999.

161. D'Sa C, Duman R. Antidepressants and neuroplasticity. Bipolar Disorder 4:183, 2002.

162. Thome J, Sakai N, Shin K, Steffen C, Zhang YJ, Impey S, et al. cAMP response element-mediated gene transcription is upregulated by chronic antidepressant treatment. J Neurosci 20:40304036, 2000

163. Chen AC, Shirayama Y, Shin KH, Neve RL, Duman RS. Expression of the cAMP response element binding protein (CREB) in hippocampus produces an antidepressant effect. Biol Psychiatry 49:753-762, 2001.

164. Shirayama Y, Chen AC, Nakagawa S, Russell DS, Duman RS. Brain derived neurotrophic factor produces antidepressant effects in behavioral models of depression. J Neurosci 22:3251-3261, 2002. 
165. Siuciak JA, Lewis DR, Wiegand SJ, Lindsay RM. Antidepressant-like effect of brain-derived neurotrophic factor (BDNF). Pharmacol Biochem Behav 56:131-137, 1997.

166. Chen B, Dowlatshahi D, MacQueen GM, Wang JF, Young LT. Increased hippocampal BDNF immunoreactivity in subjects treated with antidepressant medication. Biol Psychiatry 50:260$265,2001$.

167. Watanabe Y, Gould E, Daniels DC, Cameron H, McEwen BS. Tianeptine attenuates stress-induced morphological changes in the hippocampus. Eur J Pharmacol 222:157-162, 1992.

168. Czeh B, Michaelis T, Watanabe T, Frahm J, de Biurrun G, van Kampen M, et al. Stress-induced changes in cerebral metabolites, hippocampal volume, and cell proliferation are prevented by antidepressant treatment with tianeptine. Proc Natl Acad Sci USA 98:12796-12801, 2001.

169. Zhou R, Gray NA, Yuan P, Li X, Chen J, Chen G, et al. The anti-apoptotic, glucocorticoid receptor cochaperone protein BAG-1 is a long-term target for the actions of mood stabilizers. J Neurosci 25:4493-4502, 2005.

170. Corson TW, Woo KK, Li PP, Warsh JJ. Cell-type specific regulation of calreticulin and Bcl-2 expression by mood stabilizer drugs. Eur Neuropsychopharmacol 14:143-150, 2004.

171. Chuang DM. Neuroprotective and neurotrophic actions of the mood stabilizer lithium: can it be used to treat neurodegenerative diseases? Crit Rev Neurobiol 16:83-90, 2004.

172. Bates TE, Strangward M, Keelan J, Davey GP, Munro PM, Clark JB. Inhibition of $\mathrm{N}$-acetylaspartate production: implications for 1H MRS studies in vivo. Neuroreport 7:1397-1400, 1996.

173. Tsai G, Coyle JT. N-acetylaspartate in neuropsychiatric disorders. Prog Neurobiol 46:531-540, 1995.

174. Moore GJ, Bebchuck JM, Wilds IB, Chen G, Manji HK. Lithiuminduced increase in human brain gray matter. Lancet 356:12411242,2000

175. Moore GJ, CB, Glitz DA, et al. Lithium increases gray matter in the prefrontal and subgenual prefrontal cortices in treatment responsive bipolar disorder patients. Submitted.

176. Cirelli C, Tononi G. Differential expression of plasticity-related genes in waking and sleep and their regulation by the noradrenergic system. J Neurosci 20:9187-9194, 2000.

177. Payne JL, Quiroz JA, Zarate CA Jr, Manji HK. Timing is everything: does the robust upregulation of noradrenergically regulated plasticity genes underlie the rapid antidepressant effects of sleep deprivation? Biol Psychiatry 52:921-926, 2002.

178. Klein PS, Melton DA. A molecular mechanism for the effect of lithium on development. Proc Natl Acad Sci USA 93:8455-8459, 1996.

179. Stambolic V, Ruel L, Woodgett JR. Lithium inhibits glycogen synthase kinase- 3 activity and mimics wingless signaling in intact cells. Curr Biol 6:1664-1668, 1996.

180. Gould TD, Manji HK. Glycogen synthase kinase-3: a putative molecular target for lithium mimetic drugs. Neuropsychopharmacology 30:1223-1237, 2005.

181. Doble BW, Woodgett JR. GSK-3: tricks of the trade for a multitasking kinase. J Cell Sci 116:1175-1186, 2003.

182. Gould TD, Quiroz JA, Singh J, Zarate CA, Manji HK. Emerging experimental therapeutics for bipolar disorder: insights from the molecular and cellular actions of current mood stabilizers. $\mathrm{Mol}$ Psychiatry 9:734-755, 2004.

183. Phiel CJ, Wilson CA, Lee VM, Klein PS. GSK- $3 \alpha$ regulates production of Alzheimer's disease amyloid- $\beta$ peptides. Nature 423:435-439, 2003.

184. Gould TD, Manji HK. The wnt signaling pathway in bipolar disorder. Neuroscientist 8:497-511, 2002.

185. Jope RS, Bijur GN. Mood stabilizers, glycogen synthase kinase-3 $\beta$ and cell survival. Mol Psychiatry 7:S35-S45, 2002.

186. Ohnaka K, Tanabe M, Kawate H, Nawata H, Takayanagi R. Glucocorticoid suppresses the canonical Wnt signal in cultured human osteoblasts. Biochem Biophys Res Commun 329:177-181, 2005.

187. Smith E, Frenkel B. Glucocorticoids inhibit the transcriptional activity of $\mathrm{LEF} / \mathrm{TCF}$ in differentiating osteoblasts in a glycogen synthase kinase-3 $\beta$-dependent and -independent manner. $J$ Biol Chem 280:2388-2394, 2005.
188. Martinez A, Castro A, Dorronsoro I, Alonso M. Glycogen synthase kinase 3 (GSK-3) inhibitors as new promising drugs for diabetes, neurodegeneration, cancer, and inflammation. Med Res Rev 22:373-384, 2002.

189. Martinez A, Castro A, Dorronsoro I, Alonso M. Glycogen synthase kinase 3 (GSK-3) inhibitors as new promising drugs for diabetes, neurodegeneration, cancer, and inflammation. Med Res Rev 22:373-384, 2002.

190. Endres M, Meisel A, Biniszkiewicz D, et al. DNA methyltransferase contributes to delayed ischemic brain injury. $J$ Neurosci 20:3175-3181, 2000.

191. Ren M, Leng Y, Jeong M, Leeds PR, Chuang DM. Valproic acid reduces brain damage induced by transient focal cerebral ischemia in rats: potential roles of histone deacetylase inhibition and heat shock protein induction. Neurochem 89:1358-1367, 2004.

192. Gardian G, Yang L, Cleren C, Calingasan NY, Klivenyi P, Beal F. Neuroprotective effects of phenylbutyrate against MPTP neurotoxicity. Nanomolecular Med 5:235-241, 2004.

193. Ferrante RJ, Kubilus JK, Lee J, et al. Histone deacetylase inhibition by sodium butyrate chemotherapy ameliorates the neurodegenerative phenotype in Huntington's disease mice. J Neurosci 23:9418-9427, 2003.

194. Hockly E, Richon VM, Woodman B, et al. Suberoylanilide hydroxamic acid, a histone deacetylase inhibitor, ameliorates motor deficits in a mouse model of Huntington's disease. Proc Natl Acad Sci USA 100:2041-2046, 2003.

195. Weaver I, Cervoni N, Champagne F, et al. Epigenetic programming by maternal behavior. Nat Neurosci 7:847-854, 2004.

196. Tremolizzo L, Doueiri MS, Dong E, et al. Valproate corrects the schizophrenia-like epigenetic behavioral modifications induced by methionine in mice. Biol Psychiatry 57:500-509, 2005.

197. Manji HK, Lenox RH. Ziskin-Somerfeld Research Award. Protein kinase $\mathrm{C}$ signaling in the brain: molecular transduction of mood stabilization in the treatment of manic-depressive illness. Biol Psychiatry 46:1328-1351, 1999.

198. Birnbaum SG, Yuan PX, Wang M, Vijayraghavan S, Bloom AK, Davis DJ, Gobeske KT, Sweatt JD, Manji HK, Arnsten AFT. Protein kinase $\mathrm{C}$ overactivity impairs prefrontal cortical regulation of working memory. Science 306:882-884, 2004.

199. Einat H, MH. Cellular plasticity cascades: genes-to-behavior pathways in animal models of bipolar disorder. Submitted.

200. Bebchuk JM, Arfken CL, Dolan-Manji S, Murphy J, Hasanat K, Manji HK. A preliminary investigation of a protein kinase C inhibitor in the treatment of acute mania. Arch Gen Psychiatry 57:95-97, 2000.

201. Haggerty JJ Jr, Prange AJ Jr. Borderline hypothyroidism and depression. Аnпи Rev Med 46:37-46, 1995.

202. Bauer M, London ED, Silverman DH, Rasgon N, Kirchheiner J, Whybrow PC. Thyroid, brain and mood modulation in affective disorder: insights from molecular research and functional brain imaging. Pharmacopsychiatry 36 [Suppl 3]:S215-S221, 2003.

203. Cole DP, Thase ME, Mallinger AG, Soares JC, Luther JF, Kupfer DJ, Frank E. Slower treatment response in bipolar depression predicted by lower pretreatment thyroid function. Am J Psychiatry 159:116-121, 2002.

204. Frye MA, Denicoff KD, Bryan AL, Smith-Jackson EE, Ali SO, Luckenbaugh D, Leverich GS, Post RM. Association between lower serum free $\mathrm{T} 4$ and greater mood instability and depression in lithium-maintained bipolar patients. Am $J$ Psychiatry 156:1909-1914, 1999.

205. Joffe R. Refractory depression: treatment strategies, with particular reference to the thyroid axis. $J$ Psychiatry Neurosci 22:327331, 1997.

206. Prange A. Novel uses of thyroid hormones in patients with affective disorders. Thyroid 6:537-543, 1996.

207. Ruel J, Faure R, Dussault JH. Regional distribution of nuclear T3 receptors in rat brain and evidence for preferential localization in neurons. J Endocrinol Invest 8:343-348, 1985.

208. Schwartz HL, Oppenheimer JH. Nuclear triiodothyronine receptor sites in brain: probable identity with hepatic receptors and regional distribution. Endocrinol 103:267-273, 1978.

209. Marangell LB, Ketter TA, George MS, Pazzaglia PJ, Callahan AM, Parekh P, Andreason PJ, Horwitz B, Herscovitch P, Post 
RM. Inverse relationship of peripheral thyrotropin-stimulating hormone levels to brain activity in mood disorders. Am J Psychiatry 154:224-230, 1997.

210. Bauer M, London ED, Rasgon N, Berman SM, Frye MA, Altshuler LL, Mandelkern MA, Bramen J, Voytek B, Woods R, Mazziotta JC, Whybrow PC. Supraphysiological doses of levothyroxine alter regional cerebral metabolism and improve mood in bipolar depression. Mol Psychiatry 10:456-469, 2005.

211. Ketter TA, Wang PW. The emerging differential roles of GABAergic and antiglutamatergic agents in bipolar disorders. J Clin Psychiatry 64 [Suppl 3]:15-20, 2003.

212. Zarate CA, Quiroz J, Payne J, Manji HK. Modulators of the glutamatergic system: implications for the development of improved therapeutics in mood disorders. Psychopharmacol Bull 36:35-83, 2002.

213. Stahl SM. Finding what you are not looking for: strategies for developing novel treatments in psychiatry. NeuroRx 3:3-9, 2006.

214. Calabrese JR, Bowden CL, Sachs GS, Ascher JA, Monaghan E, Rudd GD. A double-blind placebo-controlled study of lamotrigine monotherapy in outpatients with bipolar I depression. Lamictal 602 Study Group. J Clin Psychiatry 60:79-88, 1999.

215. Calabresi P, Siniscalchi A, Pisani A, Stefani A, Mercuri NB, Bernardi G. A field potential analysis on the effects of lamotrigine, GP 47779, and felbamate in neocortical slices. Neurology 47:557-562, 1996.

216. Leach MJ, Marden CM, Miller AA. Pharmacological studies on lamotrigine, a novel potential antiepileptic drug: II. Neurochemical studies on the mechanism of action. Epilepsia 27:490-497, 1986.

217. Wang SJ, Huange CC, Hsu KS, Tsai JJ, Gean PW. Presynaptic inhibition of excitatory neurotransmission by lamotrigine in the rat amygdalar neurons. Synapse 24:248-255, 1996.

218. Zarate CA, Payne J, Quiroz JA, et al. An open-label trial of riluzole in patients with treatment-resistant major depression. Am J Psychiatry 161:171-174, 2004.

219. Zarate CA, Quiroz JA, Singh JB, Denicoff KD, De Jesus G, Luckenbaugh DA, Charney DS, Manji HK. An open-label trial of the glutamate-modulating agent riluzole in combination with lithium for the treatment of bipolar depression. Biol Psychiatry 57: 430-432, 2005

220. Cameron HA, McEwen BS, Gould E. Regulation of adult neurogenesis by excitatory input and NMDA receptor activation in the dentate gyrus. J Neurosci 15:4687-4692, 1995.

221. Zarate CA, Singh JB, Quiroz J, et al. A double-blind placebo controlled study of memantine in major depression. Am J Psychiatry 163:153-155, 2006.

222. Berman RM, Cappiello A, Anand A, et al. Antidepressant effects of ketamine in depressed patients. Biol Psychiatry 47:351-354, 2000.

223. Zarate CA Jr, Singh JB, Carlson PJ, Brutsche N, Ameli R, Luckenbaugh DA, et al. Robust, rapid, and relatively sustained antidepressant effects with a single dose of an NMDA antagonist in treatment resistant major depression: a double-blind placebo-controlled study. Arch Gen Psychiatry, in press.

224. Bleakman D, Lodge D. Neuropharmacology of AMPA and kainate receptors. Neuropharmacology 37:1187-1204, 1998.

225. Borges K, Dingledine R. AMPA receptors: molecular and functional diversity. Prog Brain Res 116:153-170, 1998.

226. Black M. Therapeutic potential of positive AMPA modulators and their relationship to AMPA receptor subunits. A review of preclinical data. Psychopharmacol (Berl) 179:154-163, 2005.

227. Li X, Tizzano JP, Griffey K, Clay M, Lindstrom T, Skolnick P. Antidepressant-like actions of an AMPA receptor potentiator (LY392098). Neuropharmacology 40:1028-1033, 2001.

228. Bai F, Bergeron M, Nelson DL. Chronic AMPA receptor potentiator (LY451646) treatment increases cell proliferation in adult rat hippocampus. Neuropharmacology 44:1013-1021, 2003.

229. Lauterborn J, Lynch G, Vanderklish P, Arai A, et al. Positive modulation of AMPA receptors increases neurotrophin expression by hippocampal and cortical neurons. J Neurosci 20:8-21, 2000.

230. Lauterborn J, Truong GS, Baudry M, Bi X, Lynch G, Gall C. Chronic elevation of brain-derived neurotrophic factor by AMPAkines. J Pharmacol Exp Ther 307:297-305, 2003.
231. Knapp RJ, Goldengerg R, Shuck C, et al. Antidepressant activity of memory-enhancing drugs in the reduction of submissive behavior model. Eur J Pharmacol 440:27-35, 2002.

232. Nicoletti F, Bruno V, Copani A, Casabona, G, Knopfel T. Metabotropic glutamate receptors: a new target for the therapy of neurodegenerative disorders? Trend Neurosci 19:267-271, 1996.

233. Maiese K, Vincent A, Lin SH, Shaw T. Group I and group III metabotropic glutamate receptor subtypes provide enhanced neuroprotection. J Neurosci Res 62:257-272, 2000.

234. Palucha A, Tatarczynska E, Branski P, et al. Group III mGlu receptor agonists produce anxiolytic- and antidepressant-like effects after central administration in rats. Neuropharmacology 46: 151-159, 2004.

235. Schoepp D. Unveiling the functions of presynaptic metabotropic glutamate receptors in the central nervous system. $J$ Pharmacol Exp Ther 299:12-20, 2001.

236. Chojnacka-Wojcik E, Klodzinska A, Pilc A. Glutamate receptor ligands as anxiolytics. Curr Opin Investig Drugs 2:1112-1119, 2001.

237. Spooren WP, Vassout A, Neijt HC, et al. Anxiolytic-like effects of the prototypical metabotropic glutamate receptor 5 antagonist 2-methyl-6-(phenylethynyl)pyridine in rodents. J Pharmacol Exp Ther 295:1267-1275, 2000.

238. Tatarczynska E, Klodzinska A, Chojnacka-Wojcik E, et al. Potential anxiolytic- and antidepressant-like effects of MPEP, a potent, selective, and systemically active mGlu5 receptor antagonist. Br J Pharmacol 1423-1430, 2001.

239. Tatarczynska E, Klodzinska A, Kroczka B, Chojnacka-Wojcik E, Pilc A. The antianxiety-like effects of antagonists of grouop I and agonists of group II and III metabotropic glutamate receptors after intrahippocampal administration. Psychopharmacol (Berl) 158: 94-99, 2001.

240. Drevets WC, Raichle ME. Neuroanatomical circuits in depression: implications for treatment mechanisms. Psychopharmacol Bull 28:261-274, 1992.

241. Drevets WC, Bogers W, Raichle ME. Functional anatomical correlates of antidepressant drug treatment assessed using PET measures of regional glucose metabolism. European Neuropsychopharmacology 12:527-544, 2002.

242. Drevets WC, Thase M, Price JC, Bogers W, Greer PJ, Kupfer DK. Antidepressant drug effects on regional glucose metabolism in major depression. Soc Neurosci Abstr 32:803.3, 2002.

243. Holthoff VA, Beuthien-Baumann B, Zundorf G, Triemer A, Ludecke S, Winiecki P, Koch R, et al. Changes in brain metabolism associated with remission in unipolar major depression. Acta Psychiatr Scand 110:184-194, 2004.

244. Kennedy SH, Evans KR, Kruger S, Mayberg HS, Meyer JH, McCann S, Arifuzzman AI, Houle S, Vaccarino FJ. Changes in regional brain glucose metabolism measured with positron emission tomography after paroxetine treatment of major depression. Am J Psychiatry 158:899-905, 2001.

245. Mayberg HS, Brannan SK, Tekell JL, Silva JA, Mahurin RK, McGinnis S, Jerabek PA. Regional metabolic effects of fluoxetine in major depression: serial changes and relationship to clinical response. Biol Psychiatry 48:830-843, 2000.

246. Nobler MS, Roose SP, Prohovnik I, Moeller JR, Louie J, Van Heertum RL, Sackheim HA. Regional cerebral blood flow in mood disorders, V. Effects of antidepressant medication in latelife depression. Am J Geriatr Psychiatry 8:289-296, 2000.

247. Nofzinger EA, Berman S, Fasiczka A, Miewald JM, Meltzer CC, Price JC, Sembrat RC, et al. Effects of bupropion SR on anterior paralimbic function during waking and REM sleep in depression: preliminary findings using [18F]-FDG PET. Psychiatry Res: Neuroimaging Section 106:95-111, 2001.

248. Saxena S, Brody AL, Ho ML, Alborzian S, Maidment KM, Zohrabi N, Ho MK, et al. Differential cerebral metabolic changes with paroxetine treatment of obsessive-compulsive disorder vs major depression. Arch Gen Psychiatry 59:250-261, 2002.

249. Smith GS, Reynolds CF, Pollock B, Derbyshire S, Nofzinger E, Dew MA, Houck PR, et al. Cerebral glucose metabolic response to combined total sleep deprivation and antidepressant treatment in geriatric depression. Am J Psychiatry 156:683-689, 1999. 